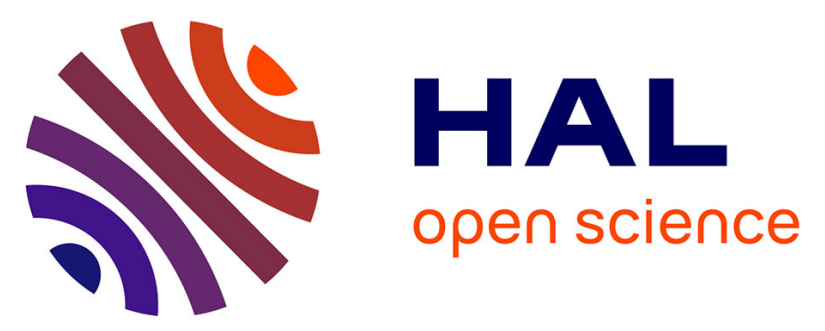

\title{
The genus Odontarrhena (Brassicaceae) in Albania: Taxonomy and Nickel accumulation in a critical group of metallophytes from a major serpentine hot-spot \\ Lorenzo Cecchi, Isabella Bettarini, Ilaria Colzi, Andrea Coppi, Guillaume Echevarria, Luigia Pazzagli, Aïda Bani, Cristina Gonnelli, Federico Selvi
}

\section{To cite this version:}

Lorenzo Cecchi, Isabella Bettarini, Ilaria Colzi, Andrea Coppi, Guillaume Echevarria, et al.. The genus Odontarrhena (Brassicaceae) in Albania: Taxonomy and Nickel accumulation in a critical group of metallophytes from a major serpentine hot-spot. Phytotaxa, 2018, 351 (1), pp.1-28. 10.11646/hytotaxa.351.1.1. hal-01826007

\section{HAL Id: hal-01826007 https://hal.science/hal-01826007}

Submitted on 26 May 2020

HAL is a multi-disciplinary open access archive for the deposit and dissemination of scientific research documents, whether they are published or not. The documents may come from teaching and research institutions in France or abroad, or from public or private research centers.
L'archive ouverte pluridisciplinaire HAL, est destinée au dépôt et à la diffusion de documents scientifiques de niveau recherche, publiés ou non, émanant des établissements d'enseignement et de recherche français ou étrangers, des laboratoires publics ou privés. 


\title{
Article
}

https://doi.org/10.11646/phytotaxa.351.1.1

\section{The genus Odontarrhena (Brassicaceae) in Albania: Taxonomy and Nickel accumulation in a critical group of metallophytes from a major serpentine hot-spot}

\author{
LORENZO CECCHI $^{1}$, ISABELLA BETTARINI ${ }^{2}$, ILARIA COLZI ${ }^{3}$, ANDREA COPPI ${ }^{3}$, GUILLAUME \\ ECHEVARRIA $^{4}$, LUIGIA PAZZAGLI ${ }^{2}$, AIDA BANI $^{5}$, CRISTINA GONNELLI $^{3}$ \& FEDERICO SELVI ${ }^{6 *}$ \\ ${ }^{1}$ Natural History Museum, Botanical Section "Filippo Parlatore", University of Florence, via G. La Pira 4, I-50121 Firenze, Italy \\ ${ }^{2}$ Department of Experimental and Clinical Biomedical Sciences and Biochemistry "Mario Serio", University of Florence, viale \\ G.B.Morgagni 50, 50134 Firenze, Italy \\ ${ }^{3}$ Department of Biology, University of Florence, via P. A. Micheli 1, I-50121 Firenze, Italy \\ ${ }^{4}$ Laboratoire Sols et Environnement, Nancy-Université, INRA, 2 avenue de la Forêt de Haye, B.P. 172 F-54505, Vandoeuvre-lès-Nancy, \\ France \\ ${ }^{5}$ Agro-Environmental Department, Faculty of Agronomy and Environment, Agricultural University of Tirana, Koder-Kamez, Tirana, \\ Albania \\ ${ }^{6}$ Department of Agrifood Production and Environmental Sciences, University of Florence, P.le delle Cascine 28, 50144 Firenze, Italy \\ *corresponding author: federico.selvi@unifi.it
}

\begin{abstract}
Metal hyperaccumulator plants represent a unique biological resource for scientific research and practical applications. Though essential, however, an adequate knowledge of the systematics of these plants is often missing. This is the case of Odontarrhena, a large but taxonomically critical group of nickel hyperaccumulators from Eurasia. We present a study on this genus in Albania, to fill a gap in our knowledge of this group from a major centre of diversity of metallicolous flora, and to contribute updated information to the Global Hyperaccumulator Database. Morphological and karyological analyses of material from field collections across all major serpentine outcrops in the country, in different years and seasons, allowed to delimit seven taxa: $O$. albiflora, $O$. chalcidica, $O$. moravensis, $O$. sibirica, $O$. decipiens, $O$. smolikana subsp. glabra and $O$. rigida. The three latter taxa have been long neglected and were resurrected in view of their clear distinctness, while commonly accepted taxa such as $O$. bertolonii subsp. scutarina and $O$. markgrafii were reduced to synonymy of $O$. chalcidica due to the lack of consistent differentiation. Polyploidy was prevalent, while diploid complements were typical of the two vicariant endemics $O$. rigida and $O$. moravensis. Types are indicated or newly designated for each entity, and nomenclatural issues are addressed based on in-depth studies of literature and herbarium material. Revised descriptions, phenology, habitat and distribution data are given for each taxon, as well as original iconographies and chromosome counts. A revised identification key is provided. Shoot nickel concentrations were determined to assess accumulation levels of taxa and populations in natural conditions and their potential for phytoextraction of this metal from the soil. With ca. 23000 and $17000 \mu \mathrm{g}$ of $\mathrm{Ni}$ $\mathrm{g}^{-1}$ of shoot dry weight, respectively, the tetraploids $O$. chalcidica and $O$. decipiens were the most promising candidates, especially the latter for its robust habit.
\end{abstract}

Keywords: Albanian flora, Alyssum s.l., Balkan endemics, Ni-hyperaccumulators, serpentine plants, systematics

\section{INTRODUCTION}

Plants that are adapted to live on metal-enriched soils and able to survive and reproduce there without suffering from toxicity are termed 'metallophytes' (Baker et al. 2010, Wójcik et al. 2017). Several categories can be distinguished based on whether these plants are restricted to metal-rich soils (obligate) or not (facultative), or the type of metal they are able to cope with. An even more outstanding specialization shown by some hundreds of angiosperms is their ability to accumulate heavy metals in concentrations well above those found in the soil, that is called hyperaccumulation. The largest group of hyperaccumulators is that of the Nickel specialists (Global Hyperaccumulator Database; http:// hyperaccumulators.smi.uq.edu.au/collection/), which exploit the high levels of this metal naturally found in the ultramafic rocks (Brooks 1980). In the above-ground parts of these species there are Ni concentrations of at least 1000 $\mu \mathrm{g} \mathrm{g}^{-1}$ shoot dry weight, and this is interpreted as a defensive strategy against natural enemies due to toxic or repellent 
effects (Palomino et al. 2007). In the last decades, Ni-hyperaccumulators have attracted a great interest for both scientific research and practical applications, especially phytoremediation and phytomining (Nkrumah et al. 2016). Hence, a robust taxonomy of these plant groups is necessary for their correct use in the field or further studies on the mechanisms of metal tolerance that require the selection of model taxa (Krämer 2010). However, this is still lacking for many groups of metallophytes worldwide (Whiting et al. 2004) and one of these is the most diverse group of Nihyperaccumulators in Europe and W Asia, Odontarrhena C.A.Mey. ex Ledebour \& al. (1830: 15).

Though established before the mid of the $19^{\text {th }}$ century this genus has almost invariably been considered as a section of genus Alyssum Linnaeus (1753: 650) [Alyssum sect. Odontarrhena (C.A.Mey. ex Ledeb.) Koch (1836: 59)] due to a general external resemblance of the plants in these two groups. On the other hand, the stamen filaments with denticulate appendages, the usual presence of solitary ovules in each locule of the ovary (vs. two ovules in Alyssum s.s.) and the usually branched (rarely simple for reduction) racemes, represent major synapomorphies that have received converging support by molecular phylogenetic analyses. Using different markers and techniques, Warwick \& al. (2008), Cecchi \& al. (2010), Rešetnik \& al. (2013) and Li \& al. (2014) have consistently shown the monophyly of the Alyssum and Odontarrhena clades, and the lack of close relationship between them in tribe Alysseae, hence their distinct generic status. According to the Alybase data source (Spaniel et al. 2015; updated version available on line at http://www.alysseae.sav.sk/), Odontarrhena includes 87 species mainly distributed in the Euro-Mediterranean and Irano-Turanian regions, from the Atlantic and W Mediterranean provinces to the Middle East and W Asia, with a single species reaching NE Asia and N America. Characterized by the habit of perennial herbs or chamaephytic shrublets, these species are all typical xerophytes restricted to dry, open habitats from sea level to over $2000 \mathrm{~m}$ a.s.l., on stony or sandy soils of different geo-mineralogical type. They are mostly found on Mg-rich soils, such as dolomites and especially serpentine. Because of their Ni-accumulation capacity (Reeves et al. 1983), several studies on the physiological and molecular mechanisms of metal tolerance have been performed on model taxa of this genus (e.g. Krämer et al. 1996, Ingle et al. 2006, Verbruggen et al. 2009), and many of these are used or considered for phytoremediation or phytomining practices since decades (Robinson et al. 1997, Chaney et al. 2005, Bani et al. 2015). However, broad phenotypic plasticity shown by populations in characters such as plant size and habit, leaf and silicle shape and pubescence on stems, leaves and fruits makes it difficult to draw the limits and circumscription of many taxa. In addition, phylogenetic analyses published so far (Mengoni et al. 2003, Warwick et al. 2008, Cecchi et al. 2010, 2013, Rešetnik et al. 2013) revealed low rates of sequence divergence in different genomic regions and provided only limited resolution of species-level relationships.

In a series of publications, the monographer Nyárády $(1928,1929 a, 1929 b, 1930,1932,1939,1949)$ provided the most complete account of Odontarrhena based on the study of herbarium material. Close examination of fine morphological variations at the individual level and narrow species concept led this author to distinguish dozens of taxa, and ultimately to produce an exceedingly complex taxonomy that has been scarcely followed by later authors. As a consequence, the number, status and nomenclature of species still differ widely in the treatments published in the last decades (Dudley 1964a, b, Greuter et al. 1986, Ball \& Dudley 1993, Hartvig 2002, Vanjeli 2015; see also Euro+Med PlantBase, http://www.emplantbase.org/home.html). Though the Alybase platform (Spaniel et al. 2015) provides a useful standard reference to the accepted and unresolved names and synonyms, it is taxonomically acritical and does not resolve the unclear points concerning the identity and status of some entities described from especially the Middle East and E Europe. The Balkan region is a major diversity centre for Odontarrhena, with 15 to 25 species, most of which are reported as endemic to more or less restricted areas (Micevski 1994, Hartvig 2002, Stevanović et al. 2003, Cecchi et al. 2010). However, most of these are poorly understood and in some cases only known from the original description and type collection. This applies especially to Albania, a small but botanically rich country hosting a number of these taxa and, in general, extensive Odontarrhena populations due to the vast occurrence of basic and ultrabasic soils such as ultramafites (Brooks 1987, Tatić \& Veljović 1992, Robertson 2012). Our field researches conducted since 2006 across this poorly known country have shown a remarkable phenotypic variation within and between the populations, but at the same time clear units which are not well reflected in the present-day taxonomy of this group. This is based on the scarce and old herbarium material from Albania kept in the major European herbaria, which is not sufficient to represent the above patterns of variation in natural populations and to understand species identities and limits. After our previous contributions on the systematics of Alysseae (Cecchi 2011, Cecchi et al. 2010, 2013), this paper aims at filling a gap into the taxonomy of Odontarrhena from a major European serpentine hotspot and to contribute original data to the recently instituted Global Hyperaccumulator Database. To this purpose, we present revised descriptions, type indications and designations, selected synonymy, original iconographies, distribution maps, chromosome data and a key to species. Levels of nickel in the shoots of native populations were also determined to get insights on the potentiality of each taxon for phytoremediation and phytomining applications. 


\section{MATERIALS AND METHODS}

Plant material and morphological analyses.-Our study is based on field collections and observations combined with the study of herbarium materials and literature. Since 2006, surveys and samplings were performed to cover as much as possible the geographic and ecological variability of the genus in Albania, resulting in collections from over 40 localities differing in altitude and soil type (Appendix 1). We visited all major serpentine outcrops in the country, from Tropoja at the north to Morava at the south (Fig. 1). Special emphasis was given to the type localities of all the specific and intraspecific taxa described from Albania (18), based on the relevant literature (Schulz 1926, Novák 1927, Nyárády 1928, 1929a, b, 1930, 1949, Meyer 2011). The study of the native populations in the type localities was crucial to understand the status and identity of several critical and often neglected names, especially those based on materials collected by F. Markgraf between 1924 and 1941. Formerly in B, these were destroyed during bombing raids in March 1943. All voucher specimens of our collections are kept in FI, with selected duplicates in B, K and the Herbarium of the Natural Sciences Museum of Tirana (not listed in Index Herbariorum, http://sweetgum.nybg.org/ science/ih/; hereinafter referred to as TIR). Additional material kept in the following herbaria was also studied: ATH, B, BEO, BEOU, BOLO, C, CL, FI, FIAF, G, JE, K, MKNH, PE, RO-HG, W and WU. Types are indicated or newly designated, when necessary, for each taxon described from Albania; links to the available images of type specimens are provided as electronic supplementary material (Table S1).

Original material and protologues of taxa described from other Balkan countries was also analyzed whenever relevant. This especially applies to bordering regions such as Serbia, Greece and Macedonia, where a number of poorly known endemics have been described even in relatively recent times (e.g. Micevski 1994).

Descriptions and iconographies were prepared based on both field notes and herbarium specimens, using standard stereomicroscopes and SEM for the observation of trichomes density and morphology. To this purpose, leaf, stem and fruits samples from dry specimens were mounted on Aluminium stubs and directly observed with a Scanning Electron Microscope (FEI ESEM-QUANTA 200) working at $30 \mathrm{kV}$.

Chromosome analyses.-Seeds were germinated in spring and autumn 2017 and 2018 after three months at $4^{\circ} \mathrm{C}$. Root tips were collected from at least five seeds per population, pretreated with $0.002 \mathrm{M}$ 8-hydroxyquinoline for $2.5 \mathrm{~h}$ at room temperature and then fixed overnight in ethanol/glacial acetic acid $(3: 1)$. When necessary, they were preserved in $70 \%$ ethanol at $3-4{ }^{\circ} \mathrm{C}$ until preparation. The meristematic tissue was then thoroughly rinsed in distilled water, hydrolysed in $1 \mathrm{M} \mathrm{HCl}$ at $60{ }^{\circ} \mathrm{C}$ for $6-7 \mathrm{~min}$ and stained in lacto-propionic orcein overnight. The meristems were finally dissected and squashed on glass slides in a drop of $45 \%$ acetic acid. Metaphase plates were examined with a Zeiss Axioscop light microscope under oil immersion $(\times 100)$, and photographed with a Nikon digital system.

Determination of nickel concentration.-In each locality and for each species, we collected healthy shoots from five different plants randomly chosen over the population distribution. As in Selvi et al. (2017), dried plants were carefully washed with demineralized water, blotted dry with filter paper, oven-dried at $50{ }^{\circ} \mathrm{C}$ for $48 \mathrm{~h}$ and grounded. Samples were mineralized by a microwave-assisted digestion with concentrated $\mathrm{HNO}_{3}$; each of the five samples was replicated three times, to obtain a mean value. Nickel concentration was estimated by an atomic absorption spectrophotometer (Analyst 200, Perkin Elmer).

\section{RESULTS}

Hereafter we present the taxonomy of Odontarrhena in Albania. Our treatment is based on a species concept that, though relatively narrow in line with current trends, recognizes infraspecific variation when this occurs at the individual level within populations. Hence, species are defined based on correlations between relatively stable morphological characters with karyological features, ecological traits and distribution patterns. Flowering and fruiting time is also widely variable between species, often independently from altitude or habitat, providing a useful taxonomic character. Molecular data from phylogenetic papers cited in the introduction are also considered, though these are mostly of limited utility (see above) to separate morphologically distinct units, even with allopatric distribution and different chromosomal or phenological features. 


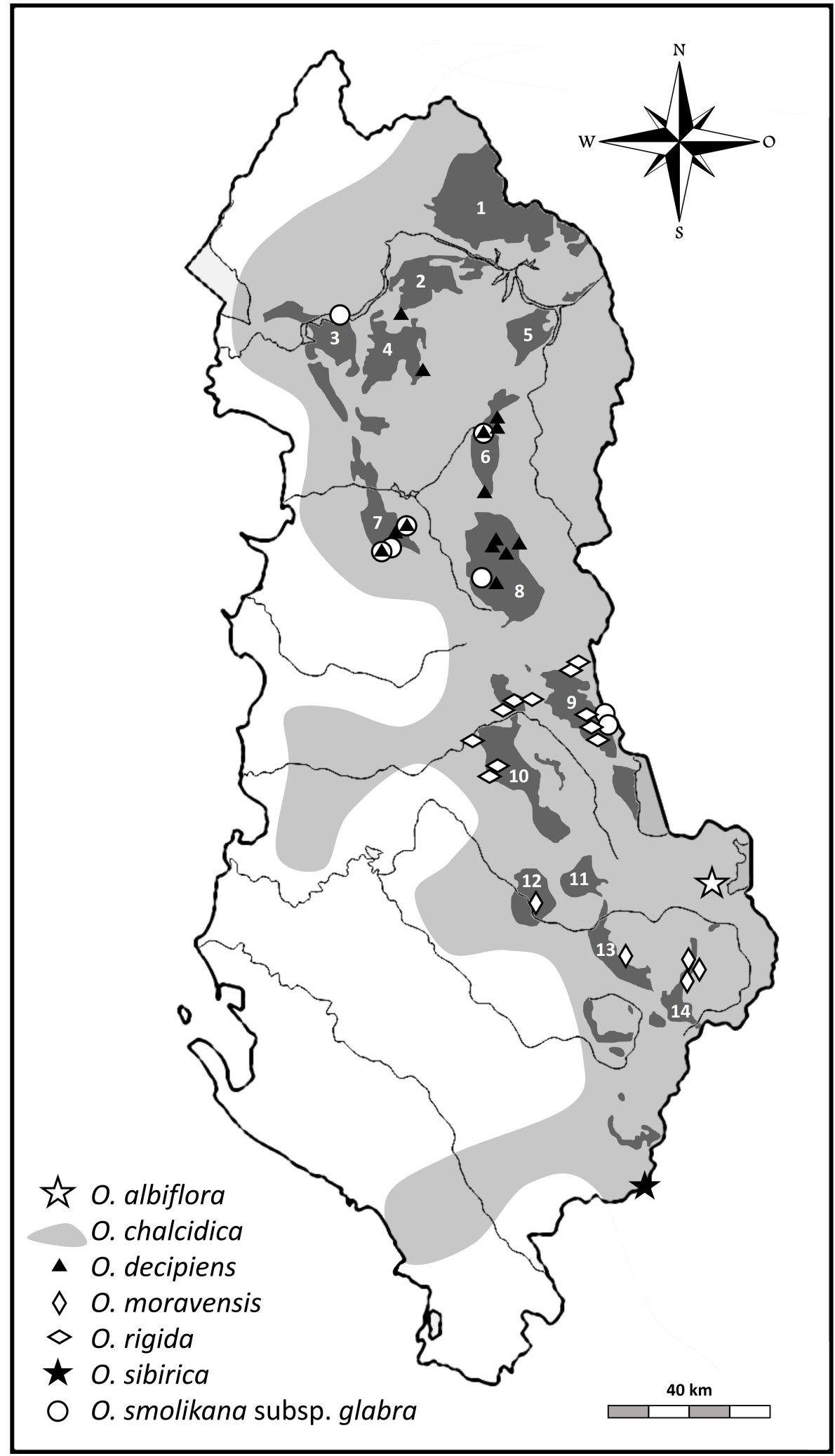

FIGURE 1. Distribution of Odontarrhena in Albania; the range of $O$. chalcidica is given as light grey area, the other taxa as symbols (in legend); major serpentine outcrops are represented as dark grey spots and numbered from the north to the south. 1: Tropoja, 2: Krrabi, 3: Gomsiqe, 4: Puke, 5: Kukesi, 6: Lure, 7: Skenderbeu, 8: Bulqize, 9: Shebenik, 10: Shpati, 11: Vallamara, 12: Devolli, 13: Voskopoja, 14: Morava (after Bani et. al. 2017, modified). 
Odontarrhena C.A.Mey. ex Ledeb.

( $\equiv)$ Alyssum sect. Odontarrhena (C.A.Mey. ex Ledeb.) W.D.J.Koch.

Type:-Odontarrhena microphylla Ledeb. (1830: 15). [= O. obovata C.A.Mey. (in Ledebour \& al. 1831: 61) nom. cons.].

Small chamaephytes or long-lived cespitose herbs with robust taproot, with or without sterile stems and leaf rosettes at the base. Most parts of the plants covered with stellate hairs. Inflorescence a compound corymbus, rarely reduced to a simple raceme. Sepals ovate, green with a scarious margin. Petals yellow, cuneate-spathulate. Stamens filaments with denticulate appendages. Fruit (silicles) with two seeds, one for each loculus (only occasionally two).

Literature information on breeding systems is lacking, but field observations suggest that the bright yellow flowers are visited by a wide variety of pollinating insects including bees, hover flies, flies, wasps and small beetles. Personal observations on plants cultivated for years in the botanical garden of the Florence University suggest that allogamy is the main breeding system. However, selfing is likely to occur also in some taxa/populations, similarly to some species of Alyssum s.s. (Hegi 1986, Rusterholz et al. 2012, Cecchi et al. 2013). The seven taxa native to Albania are presented below in alphabetical order.

1. O. albiflora (Meyer 2011: 63) Španiel, Al-Shehbaz, D.A.German \& Marhold in Španiel et al. (2015: 2483). (झ) Alyssum albiflorum F.K.Mey.

Holotype:-ALBANIA. “Pogradec, Shengjergj, Südabfall des Mali-i-Thatë, 1000-1300 m, Kalk”, 05/07/1959, F.K. Meyer, Flora Albanica no. 3552, JE00016682, JE!

Isotype:-JE00016683, JE!

Flowering stems erect 10-30(40) $\mathrm{cm}$, whitish for dense hairs throughout, often reddish beneath. Sterile shoots with spathulate basal leaves, 7-15 $\times 2-4 \mathrm{~mm}$, rounded at apex, greyish on upper surface for 10- to 23-rayed, dense (but 1-layered) hairs, ca. $0.6 \mathrm{~mm}$ across, white-silvery on lower surface for denser, overlapping hairs of similar shape and size. Inflorescence corymbose, with secondary branching, partial racemes short, each with 10-12 fruits on erectopatent, thick pedicels. Sepals 1.9-2.5 mm long, with ca. 10-rayed hairs, $0.3 \mathrm{~mm}$ across. Petals 3-3.5 mm long, external surface with sparse hairs like those on sepals. Style $1.5-2 \mathrm{~mm}$, with stellate hairs in the lower part. Siliculae broadly elliptic-obovate, 3.5-4.5 × 2.3-3.5 mm; valves whitish, densely covered with 8-12-rayed, overlapping hairs $0.3 \mathrm{~mm}$ across. Seeds 2-2.4 $\times 1.3-1.5 \mathrm{~mm}$, including a wing ca. $0.25 \mathrm{~mm}$ wide. Figs. 2, 3A, 6A, 7A.

Phenology. Flowering from late May to mid July, fruit ripening from late June to August (Fig. 4).

Chromosome number. $2 \mathrm{n}=32$ (Fig. $5 \mathrm{H}$ ); plants from the type locality.

Distribution and ecology. This species is an extremely rare endemic only known from the type locality on the southern slope of Mt. Thatë between Pogradec and Korça (Fig. 1; Appendix 1). Here, it grows on SW-facing limestone cliffs from 900 to $1300 \mathrm{~m}$.

Nickel accumulation. Over $2000 \mu \mathrm{g} \mathrm{g}^{-1} \mathrm{dw}$ of Ni were detected in leaf samples of this species (Table 1), despite its occurrence on limestone rocks.

Comments. This species was previously known from the single type gathering only, and the name A. albiflorum was unresolved according to The Plant List (http://www.theplantlist.org/). Our finding in the type locality (June and October 2017) allows to confirm its specific status and distinctness based on morphological and ecological characters. This is the only Albanian species in this genus that grows exclusively on calcareous rocks. 


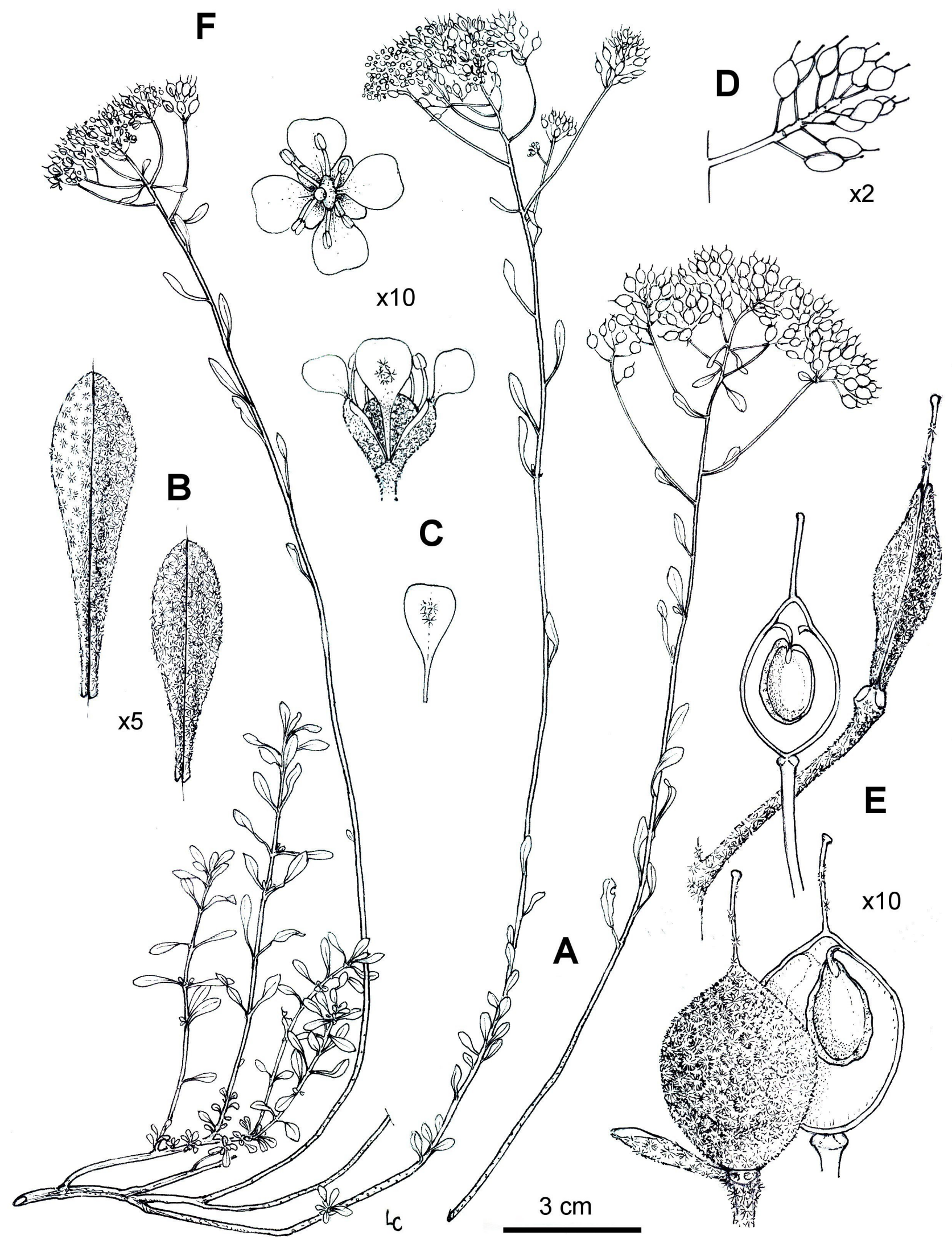

FIGURE 2. O. albiflora. A) habit (left: flowering and early fruiting plant with sterile shoots; right: fruiting stem); B) cauline leaves showing their upper (left) and lower surface (right); C) flower from above and in lateral view, and single petal; D) lateral fruiting raceme; E) silicles of different size in lateral, inner and outer view. Original drawing by L. Cecchi (based on FI050841 and FI052166). 


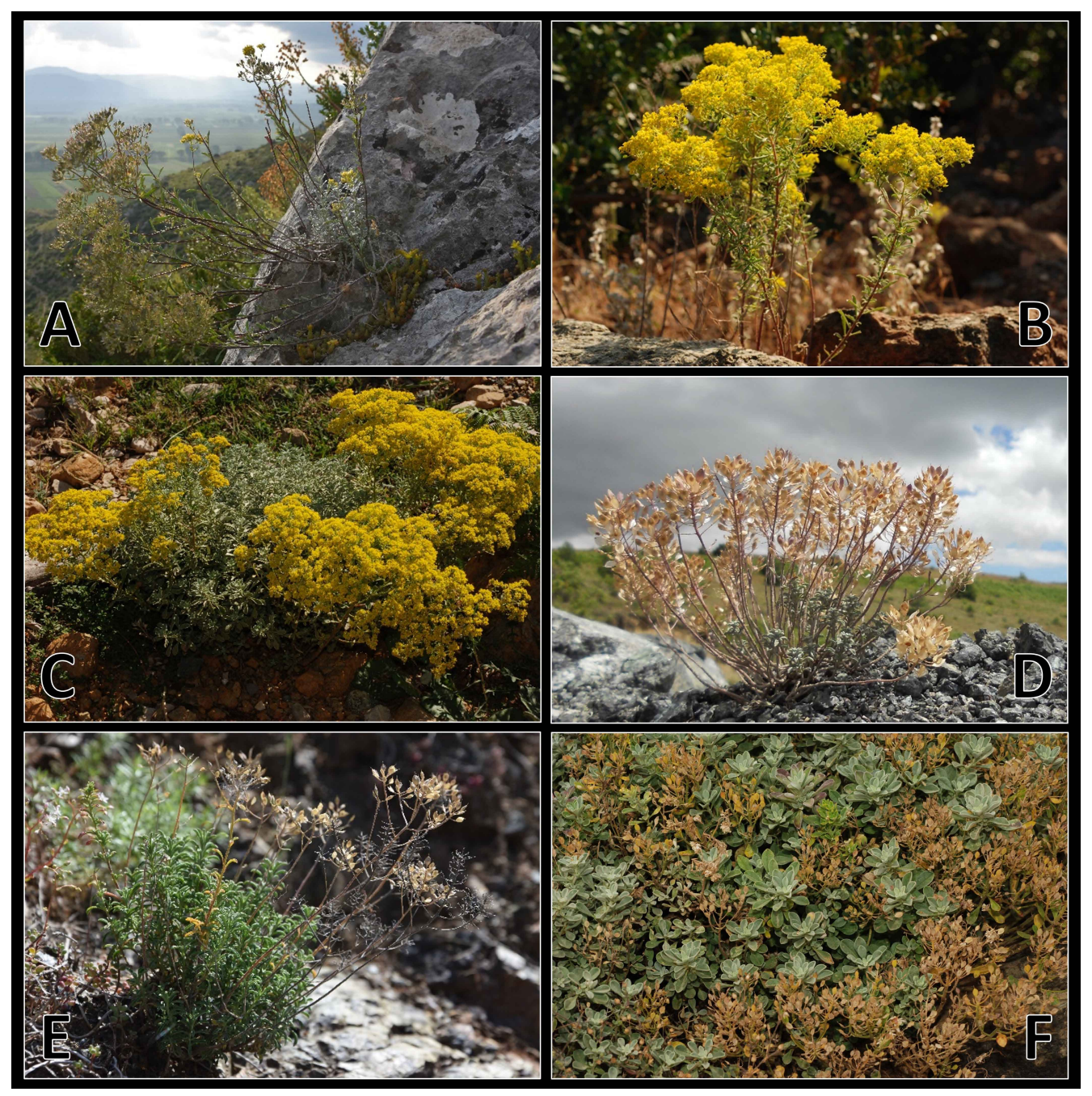

FIGURE 3. The Albanian taxa of Odontarrhena in their natural environment: A) O. albiflora (Mt. Tathë); B) O. chalcidica (Pishkash); C) O. decipiens (Bulqizë); D) O. moravensis (Voskopojë); E) O. rigida (Mt. Shpat); F) O. smolikana subsp. glabra (Mt. Shebenik).

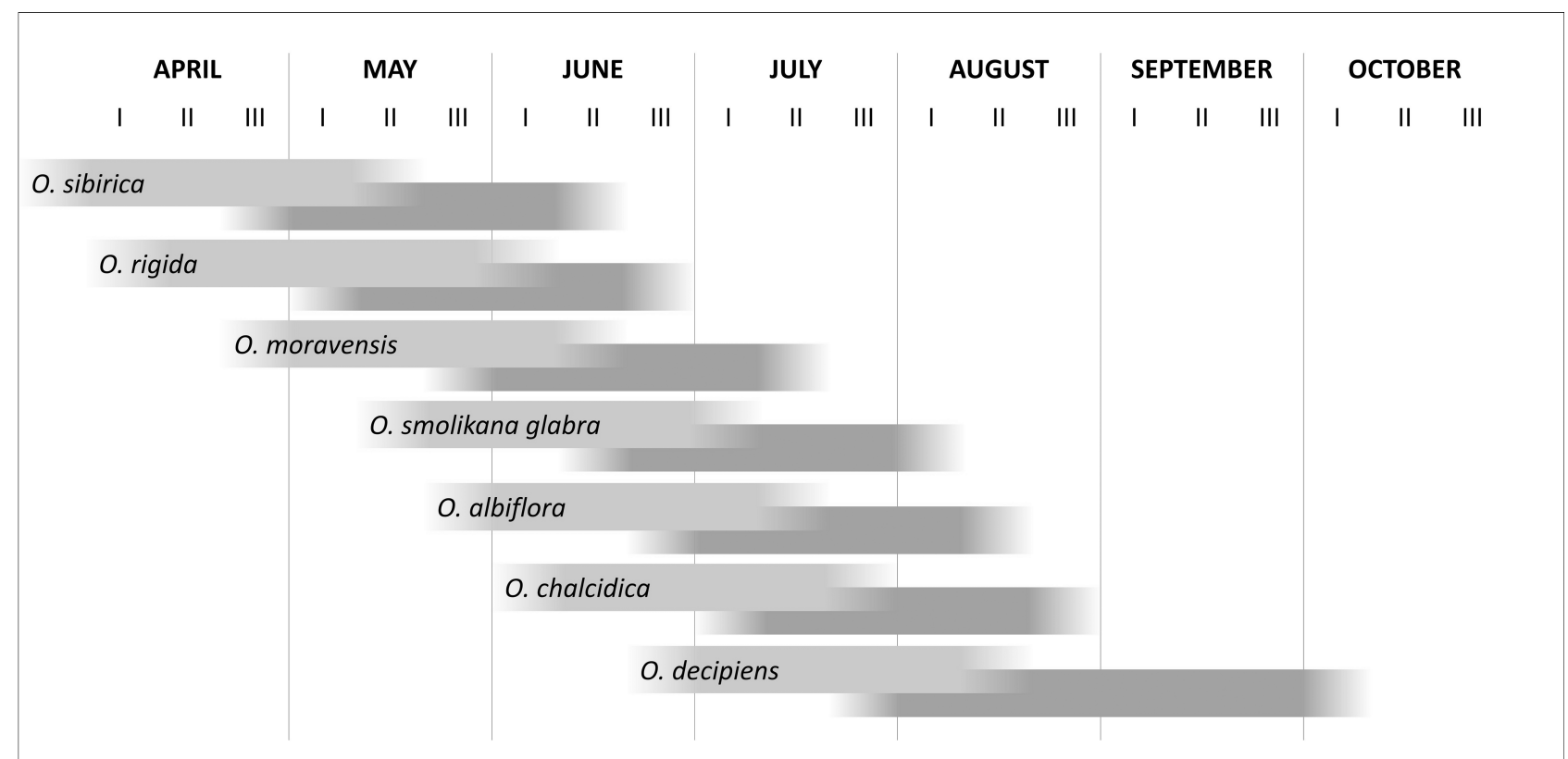

FIGURE 4. Phenological differences between taxa of Odontarrhena in Albania. Bars in light grey indicate the time interval between the decade in which at least $50 \%$ of the population is in flower and the decade when full flowering (100\%) of the population occurs; bars in dark grey indicate the same interval for the fruiting process $(50 \%-100 \%$ of the population with ripe fruits). 
2. O. chalcidica (Janka 1872: 175) Španiel, Al-Shehbaz, D.A.German \& Marhold in Španiel et al. (2015: 2484).

(三) Alyssum chalcidicum Janka. $\equiv$ A. murale subsp. chalcidicum (Janka) Contandriopoulos (1969: 323).

Lectotype (designated here):-GREECE. "in montibus inter Hierisso et Gomati Chalcidices; in arvis atque locis silvaticis ad agrorum margines", 04/08/1871, V. Janka, WU1938-0001420, WU!

Isolectotypes:- “in montibus inter Hierisso et Gomati Chalcidices; in arvis atque ad agrorum margines”, Herb. Haussknecht, JE00003077, JE!; “in montibus inter Hierisso et Gomati Chalcidices”, B 10 0058222, B!; GH00018476, GH!; Herb. Churchill, K000484603, K!; Herb. Reichenbach, W1889-0038856, W!; "In campi ad silvarum margines inter pag. Hierisso et Gomati chalcidices”, FI010117, FI!; ex Herb. Groves, FI018015, FI!; JE00003078, JE!; Herb. Halácsy, WU0033143, WU!

(=) A. markgrafii O.E.Schulz in Markgraf (1926: 422), syn. nov. $\equiv$ O. markgrafii (O.E.Schulz) Španiel, Al-Shehbaz, D.A.German \& Marhold in Španiel et al. (2015: 2485).

Neotype (designated here):-ALBANIA. "prefettura di Elbasan, distretto di Librazhd, pietraia calcarea presso la vetta del Gur i Pishkashit, 1080 m, 41 5'44.53”N, 20³1'10.12”E”, 14/07/2016, I. Bettarini, L. Cecchi, A. Coppi \& F. Selvi, FI050424, FI!

Isoneotypes:-B!, Herb. Cecchi no. 3335!

The original collections (syntypes) of A. markgrafii ("Çermenika: Gur i Pishkashit bei Qukës, 1100 m, Kalk, den Gipfel bedeckend", 19/06/1924, F. Markgraf no. 773; "Shpat: Shelcan, offene Serpentinschuttflur, massenhaft, 800 m”, 01/06/1924, F. Markgraf no. 501) were kept in B but were destroyed and no duplicates could be traced in the other European herbaria hosting Markgraf's materials (E, TIR, Z). We collected material from both type localities above; the neotype selected here comes from the first one and fits the original description of the species (O.E. Schulz in Markgraf 1926).

(=) A. janchenii Nyár. in Novák (1927: 109), syn. nov.

Lectotype (designated here):-ALBANIA. "Nord-Albanien: Umgebung von Shkodra. Abhänge des Kleinen Bardanjolt, Serpentin", 08/06/1916, E. Janchen, WU0073381, WU!

Isolectotype:-WU0073382, WU!

Other original material:-ALBANIA. "in aridis serpentinis infra Scutari et Renci”, 11/06/1897, A. Baldacci, Iter Albanicum Quintum no. 241, BM000750162 [flowering specimen only], BM!; K000484615 [flowering specimen only], K!; WU00679672, WU! "Im Schotter des Nerfuša-Baches bei dessen Einmündung in den Drin (Östl. Von Skodra)”, 18/06/1916, E. Janchen, WU0033158, WU!

Although the name was first published in a paper on the flora of Serbia (Novák 1927), it was explicitly based on Nyárády’s diagnosis of Albanian collections; in a later publication Nyárády himself (1928: 93-96), mentioned the provenance of the original material by Janchen, which accounts for the specific epiteth.

(=) A. bertolonii subsp. scutarinum Nyárády (1928: 101), syn. nov. $\equiv$ O. bertolonii subsp. scutarina (Nyár.) S̆paniel, Al-Shehbaz, D.A.German \& Marhold in Španiel et al. (2015: 2485).

Lectotype (designated here):-ALBANIA. "in aridis serpentinis / infra Scutari et Renci”, 09/08/1897, A. Baldacci, Iter Albanicum Quintum no. 241, WU0033163, WU!

Isolectotypes:-BM000750162 [fruiting specimen only], BM!; K000484615 [fruiting specimen only], K!

(=) A. chlorocarpum var. subellipticum Nyárády (1928: 121), syn. nov.

Holotype:-ALBANIA. “Lurija”, 06/07/1913, N. Košanin, BEO07360 [central specimen], BEO!

(=) A. punctatum f. divergens Nyárády (1928: 86), syn. nov.

Holotype:-ALBANIA. "Lurija”, 06/07/1913, N. Košanin, BEO07360 [left specimen], BEO!

(=) A. elatius Meyer (2011: 64), syn. nov. $\equiv$ O. elatior (F.K.Mey.) Španiel, Al-Shehbaz, D.A.German \& Marhold in Španiel et al. (2015: 2484; 'elatius').

Holotype:-ALBANIA. “Korça, Mali i Moravës, bei Drenova, ca. 1100-1200 m, Serpentin. 12/09/1961, F.K. Meyer, Flora Albanica no. 6148, JE00016684, JE!

Flowering stems erect 10-60(100) cm, thick and somewhat rigid in fruit. Basal sterile shoots rarely numerous when present, with leaves up to $20 \times 6 \mathrm{~mm}$, spathulate, obtuse, usually gutter-like folded, greenish above with a single layer of hairs, greyish below for two layers of hairs with 6-20 rays, $0.3-0.6 \mathrm{~mm}$ across. Leaves on flowering stems linear to narrowly spathulate, longer than those on sterile shoots, often incurved and with smaller leaves at the axil. Inflorescence a broad, compound corymb, 3- to 4-branched. Partial racemes usually with 10-20 fruits. Fruiting pedicels delicate, erecto-patent, the lowermost sometimes slightly flexuous. Sepals $1.5-2 \times 0.7-1.0 \mathrm{~mm}$. Petals $2-3 \mathrm{~mm}$. Style $0.8-1.5$ $\mathrm{mm}$. Siliculae $2.5-4.3 \mathrm{~mm}$ long, elliptic to suborbicular, retuse, rounded or subacute at apex, obtuse to rounded at base, symmetrical; valves flat to slightly inflated, not undulate, indistinctly veined; hairs on valves absent or sparse, never overlapping, $0.15-0.3 \mathrm{~mm}$ across, with $8-16$ appressed rays. Seeds $1.5-2.0 \mathrm{~mm}$ long, including a wing $0.3-0.5 \mathrm{~mm}$ wide. Figs. 3B, 6B, C, 7B, C, 8 .

Phenology. Flowering from June to July, fruit ripening from July to August (Fig. 4). 
TABLE 1. Nickel concentration in leaf samples $\left(\mu \mathrm{g} \cdot \mathrm{g}^{-1} \mathrm{dw}\right.$ ) of six out of seven taxa of Odontarrhena from Albania; minimum and maximum values, determined in different populations/sites (except for O. albiflora, only one population), are given as means \pm standard deviation of five plants (three replicates per plant); details of the voucher specimens are given in Appendix 1.

\begin{tabular}{|c|c|c|c|c|}
\hline \multirow{2}{*}{ Species } & \multicolumn{2}{|c|}{ Ni concentration } & \multirow{2}{*}{$\begin{array}{l}\text { Origin } \\
(\min , \max )\end{array}$} & \multirow{2}{*}{$\begin{array}{l}\text { Vouchers } \\
\text { (min, max) }\end{array}$} \\
\hline & $\min$ & $\max$ & & \\
\hline O. albiflora & - & $2700 \pm 100$ & Mt. Thatë & FI050840 \\
\hline O. chalcidica & $4600 \pm 500$ & $23000 \pm 1000$ & Barmash, Pogradec & FI050417, FI050416 \\
\hline O. decipiens & $7900 \pm 500$ & $17300 \pm 1300$ & Fierzë, Shtamë & FI050444, FI050442 \\
\hline O. moravensis & $5500 \pm 100$ & $14300 \pm 1300$ & Mt. Morave, Voskopoje & FI050828, FI050441 \\
\hline O. rigida & $7500 \pm 500$ & $17100 \pm 700$ & Mt. Shpat, Mt. Shebenik & FI050434, FI050437 \\
\hline $\begin{array}{l}\text { O. smolikana subsp. } \\
\text { serpentinicola }\end{array}$ & $7700 \pm 400$ & $14000 \pm 2000$ & Shtamë, Krastë & FI050431, FI050831 \\
\hline
\end{tabular}

Chromosome number. $2 \mathrm{n}=32+0-4 \mathrm{~B}$ (Fig. 5D, E). Counts were performed on plants from five populations: near Pogradec (FI050416), Mt. Shpat near Elbasan (one of the two type localities of O. markgrafii, FI050423), Mt. Shebenik near Skënderbej (FI050428), Renc near Skhodër (type locality of O. bertolonii subsp. scutarina and $A$. janchenii, FI050420) and Mt. Morave near Drenova, type locality of $O$. elatior (FI052165; Fig. 5E). Supernumerary B-chromosomes were observed in the population from Mt. Shpat (Fig. 4D) and probably from Pogradec. Plants of O. muralis (Waldst. \& Kit.) Endl. from the type locality in Romania (Deva), investigated here for the first time, were instead diploid with $2 \mathrm{n}=16$ (Fig. 5A). Previous counts in the A. murale complex from other Balkan countries reported both $2 \mathrm{n}=16$ and $2 \mathrm{n}=32$ (Jalas et al. 1996).

Distribution and ecology. Widely distributed throughout Albania, especially in the northern, central and eastern parts, less frequent in the south (Fig. 1). It grows on ultramafic rocks and other peridotites, less frequently on schists and flysch, from 50 to $1300 \mathrm{~m}$ a.s.l. It is a synanthropic plant clearly preferring disturbed habitats such as ruderal sites, mining areas, road margins, cultivated and abandoned lands, dry pasturelands and fields.

Nickel accumulation. Shoot Ni-levels in this species were variable, though always well above $1000 \mu \mathrm{g} \mathrm{g}^{-1} \mathrm{dw}$ when in plants from serpentine soil. The maximum concentration, detected in plants from Pogradec, was over five times higher than the minimum value detected in plants from mixed serpentine-schist soil south of Erseke (Table 1).
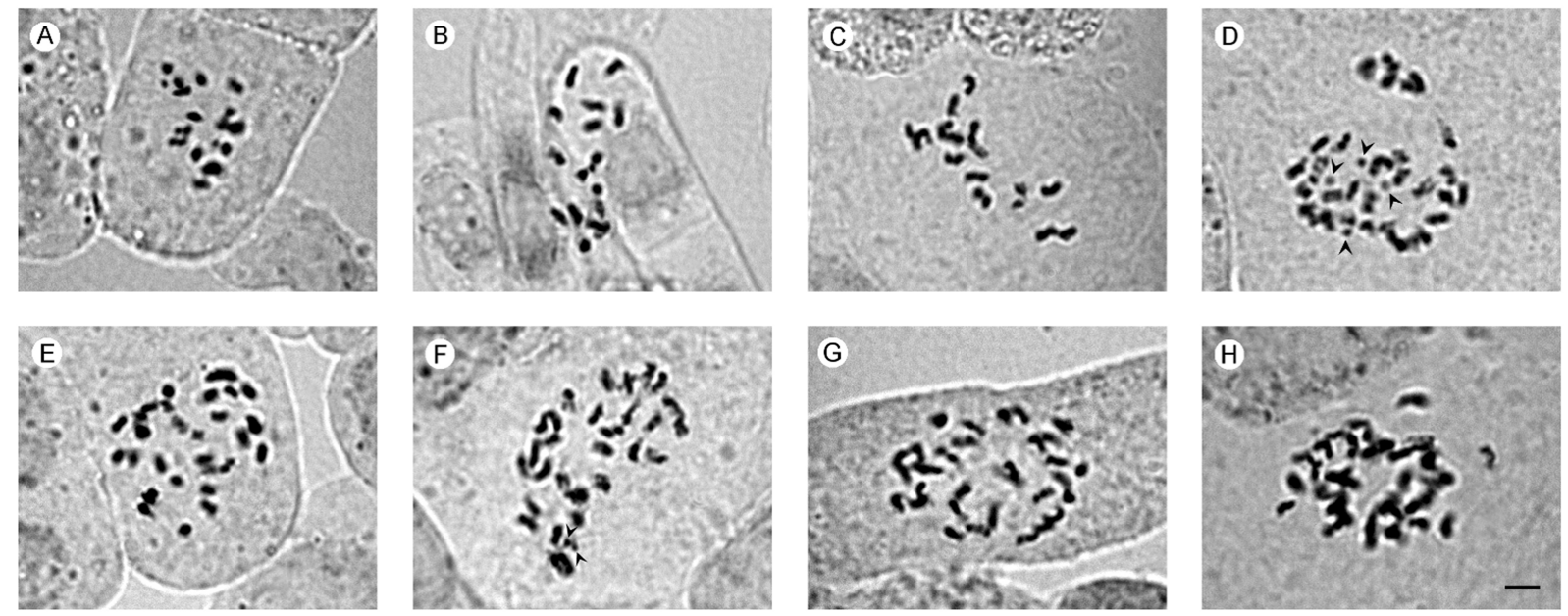

FIGURE 5. Micrographs of chromosome metaphase plates of: A) O. muralis (Romania, Deva, type locality, FI052171), 2n = 16; B) $O$. rigida, $2 \mathrm{n}=16$; C) $O$. moravensis, $2 \mathrm{n}=16$; D) $O$. chalcidica (“A. markgrafii”, FI050423), $2 \mathrm{n}=32+4 \mathrm{~B}$; E) $O$. chalcidica (type locality of A. elatius, FI052165), 2n=32; F) O. decipiens (FI050443), 2n=32+2B; G) O. smolikana subsp. glabra, 2n = 32; H) O. albiflora, 2n = 32. Scale bar $=5 \mu \mathrm{m}$. The B-chromosomes are indicated by arrow heads. 

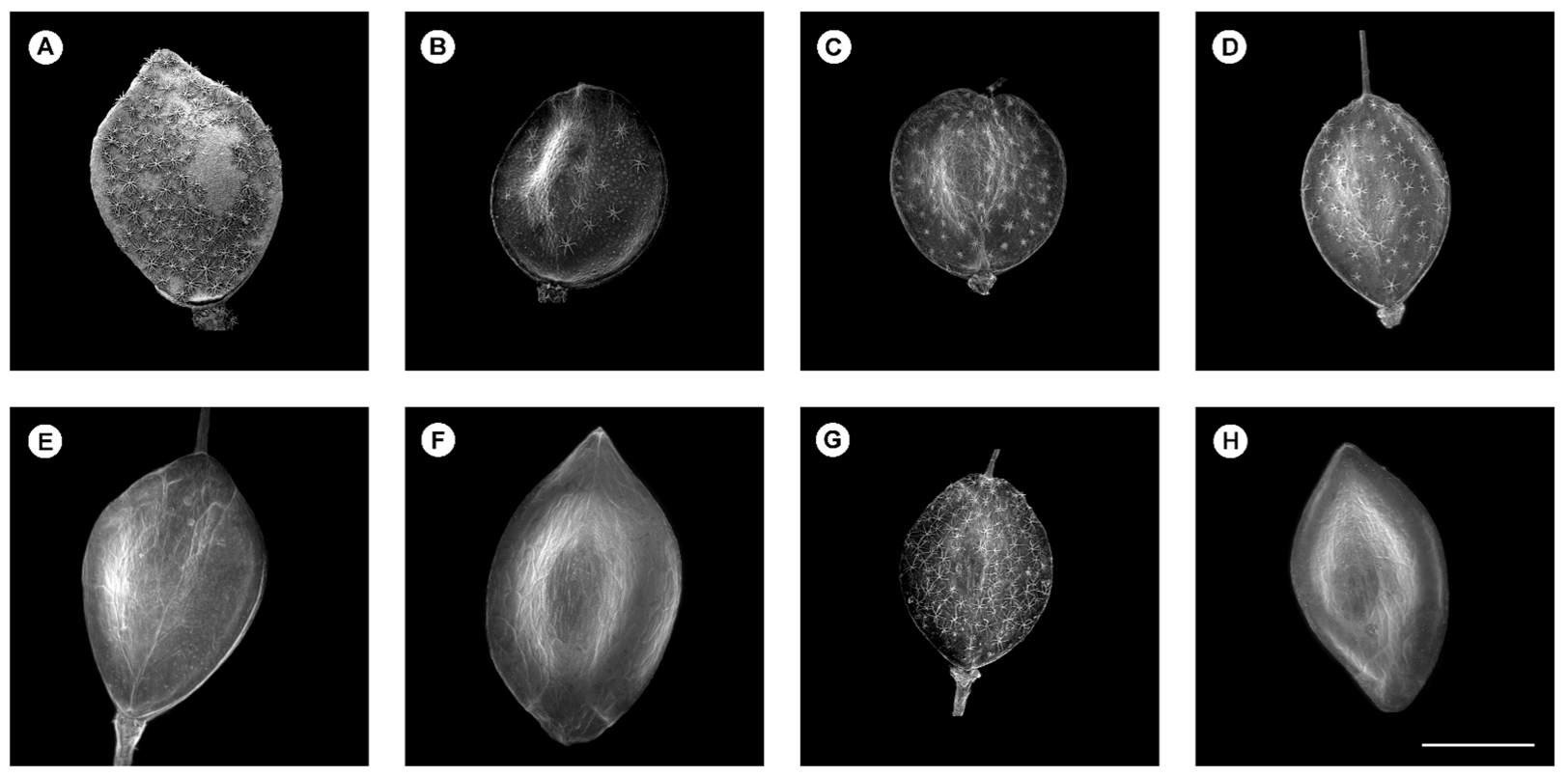

FIGURE 6. SEM micrographs of silicles of: A) O. albiflora (FI050840); B) O. chalcidica (neotype of A. markgrafii, FI050424); C) O. chalcidica (Greece, near Thessaloniki, isolectotype, FI010117); D) O. decipiens (FI050445); E) O. smolikana subsp. glabra (FI050433); F) O. moravensis (FI050441); G) O. muralis (Romania, Deva, type locality, FI050439); H) O. rigida (neotype, FI050434). Scale bar = $2 \mathrm{~mm}$.

Comments. Odontarrhena chalcidica belongs to the species complex of $O$. muralis and was included until recent times within the latter, as a subspecies (Contandriopoulos 1967) or as "variant" (Ball \& Dudley 1993, Jalas et al. 1996, Cecchi et al. 2010). At present, however, it is mostly recognized as a separate species and indicated from most of the southern Balkan countries: Serbia, Kosovo, Macedonia, Greece and possibly Bulgaria (Hartvig 2002, Marhold 2011, Spaniel et al. 2015). Examination of $O$. muralis in the type locality in Romania (citadel of Deva, FI052171) confirmed that $O$. chalcidica differs by the less densely pubescent stems, the obtuse leaves, the smaller flowers, the more slender fruiting pedicels, and especially the silicles with at most few, scattered and minute trichomes (vs. dense in O. muralis, Fig. 6G). It also differs ecologically in its clear preference for soils with high levels of $\mathrm{Mg}$, especially serpentine, while O. muralis is usually found on limestone soils or other substrates (including volcanic rocks as in the type locality), but not on serpentine (see also Hartvig 2002).

As in the Greek populations, the Albanian plants of $O$. chalcidica show very broad variations in size, branching degree of flowering stems, shape and hairs on the silicle valves, even at the individual level. At a close examination of specimens from their respective type localities, both $O$. markgrafii and $O$. bertolonii subsp. scutarina resulted clearly within the range of phenotypic variation of this species and are here included in its circumscription, in contrast with most of the literature (Ball \& Dudley 1963, Jalas et al. 1996, Spaniel et al. 2015). When tested on numerous individuals complete of all parts, the characters used to separate these taxa in treatments based on herbarium material appeared artificial. The former species (O. markgrafii) is reported to differ from $O$. muralis by substantially the same characters of $O$. chalcidica (more slender habit, smaller petals, silicles glabrous or with sparse hairs). Schulz (in Markgraf 1926: 422 ) indicated that $O$. markgrafii differs from typical $O$. chalcidica by the smaller flowers and the trichomes on the stem, which are oblong and with less numerous (6-10), longer rays (vs. circular "disciform" hairs with 10-20, short rays, fig. 7B, C). However, we observed that these two morphologies are connected by a continuous series of intermediate types and most of these are found in plants from localities in N and C Albania, including the typical ones of $O$. markgrafii. This shows the scarce taxonomic value of this character and supports inclusion of $O$. markgrafii in $O$. chalcidica, as proposed by Hayek (1927). Odontarrhena bertolonii subsp. scutarina was mainly distinguished from $O$. muralis in view of the narrower silicles with elliptic shape, subacute at the apex. For this character the Albanian plants were referred to the Italian endemic $O$. bertolonii (Desv.) Jord. \& Fourr., with similar silicles, though Nyárády himself $(1930,1949)$ correctly excluded this affinity in his last papers. Indeed, plant habit, leaf shape and branching pattern of the inflorescence as displayed in the field are clearly different in these two taxa, which supports the phylogenetic distance between them revealed by molecular data (Cecchi et al. 2010). Based on these, the Albanian plants belong to 
the $O$. muralis clade, while $O$. bertolonii is included in a different clade together with other W Mediterranean endemics (Cecchi et al. 2013). Odontarrhena elatior ('elatius') was described based on a single fruiting collection from the region of Korça (Meyer 2011). Close examination of material from the type locality on the Morava massif (Appendix 1) showed that the diagnostic characters mentioned in the protologue are still in the range of variation of $O$. chalcidica. In some plants, the elliptic, subacute silicles and the numerous sterile shoots with small leaves, uncommon in typical O. chalcidica, suggest possible hybridization with $O$. moravensis, the other taxon in this area.
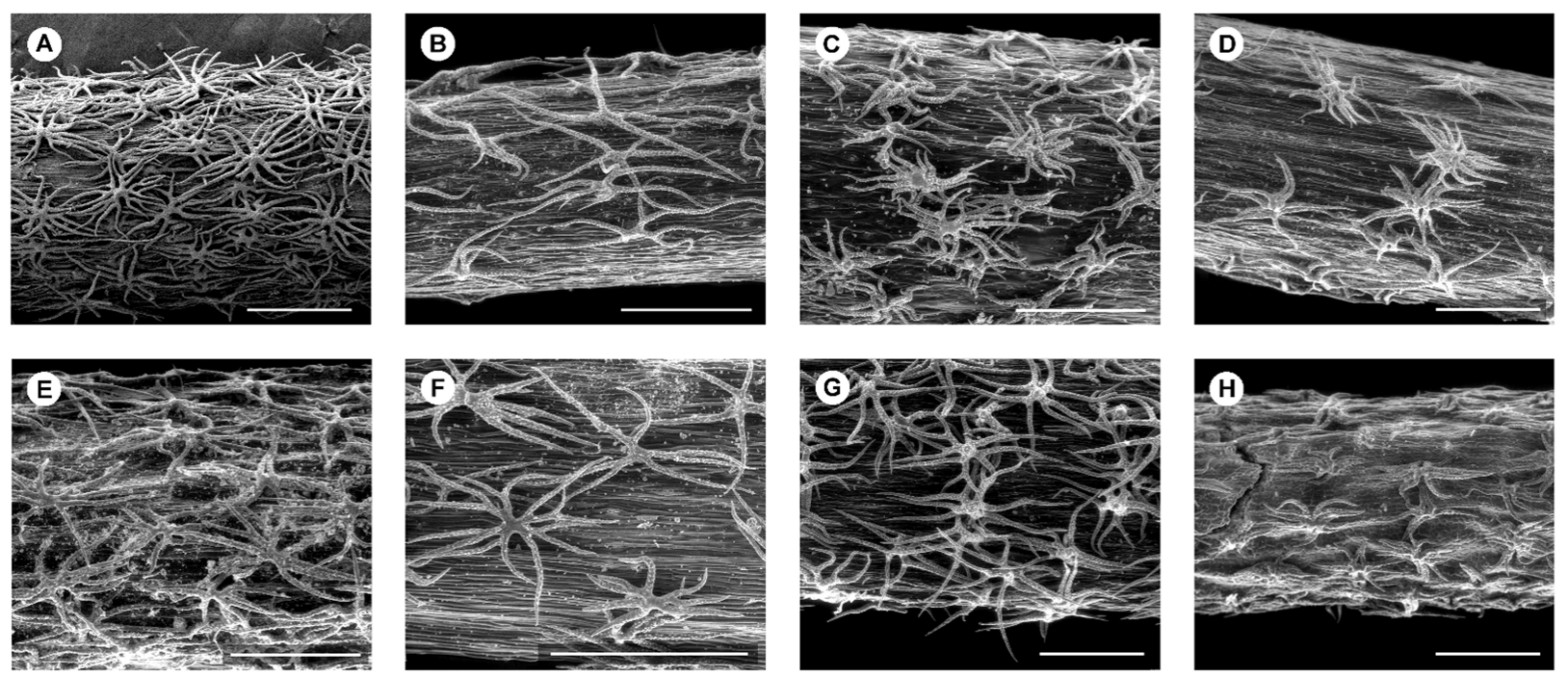

FIGURE 7. SEM micrographs of trichomes on the median part of flowering stems of: A) O. albiflora (FI050840); B) O. chalcidica (neotype of A. markgrafii, FI050424); C) O. chalcidica (FI050422); D) O. decipiens (FI050445); E) O. smolikana subsp. glabra (FI050433); F) O. moravensis (FI050441); G) O. muralis (FI050439 type locality, Romania); H) O. rigida (neotype, FI050434). Scale bar $=500 \mu \mathrm{m}$.

\section{O. decipiens (Nyárády 1928: 113) L.Cecchi \& Selvi, comb. nov.}

(三) Alyssum decipiens Nyár.

Lectotype (designated here):-GREECE. "in summis saxosis montis Smolika distr. Konitza", 18/07/1896, A. Baldacci, Iter Albanicum

(Epiroticum) Quartum no. 206, WU0043221, WU!

Isolectotype:- “in saxosis regionis Abietinarum m. Smolika supra Kerasovo distr. Konitza”, BM000750128, BM!

We were unable to trace a third specimen whose image appeared in a later publication by Nyárády (1929b: 44).

(=) A. kosaninum var. obovatifolium Nyárády (1928: 97), syn. nov.

Holotype:-ALBANIA. “Lurija”, 06/07/1913, N. Košanin, BEO07360 [right specimen], BEO!

(=) A. balkanicum Nyárády (1930: 393), syn. nov. [Latin diagnosis published later by Markgraf (1931: 337)]. - A. balkanicum f. elatum

Nyárády (1930: 394), nom. inval. - A. balkanicum var. elatum Nyárády (1949: 157), nom. inval.

Neotype (designated here):-ALBANIA. "Prefettura di Durazzo (Durrës), Distretto di Croia (Krujë), versante occidentale del Maja e

Liqenit, pietraia serpentinosa sul primo tornante a gomito subito oltre il passo di Shtamës, $1010 \mathrm{~m}, 41^{\circ} 31^{\prime} 11.42^{\prime}$ 'N, 1952'51.85”E”,

18/07/2016, I. Bettarini, L. Cecchi, A. Coppi \& F. Selvi, FI050442, FI!

Isoneotypes:-B!; FI050893, FI!; K!; JE!; TIR!; Herb. Cecchi no. 3372!

Alyssum balkanicum was originally described in two forms, later treated as varieties; "f. elatum" is here selected as the one corresponding to the type, and is thus invalid with respect to the autonym (ICN Art. 26.2; McNeill et al. 2012). Designation of a neotype is required since the following original collections (syntypes, all listed as "f. elatum") were lost during the war and no duplicates were found in E, TIR or Z: "Nord-Albanien: Landschaft Matja [Mat river] (östlich Kruja) [...] Zalli Germanit, Serpentinschutt, 500 m ü.d.M.", 12/07/1928, F. Markgraf \& W. Pieper, no. 1614 \& 1615; Proj Rrepës zw. Ben [Bejne] und Cëruj [Ceruje], Serpentingeröll, 400 m ü.d.M.", 27/05/1928, F. Markgraf \& W. Pieper, no. 1118; "Nord-Albanien: Östliche Matja, Mal i Alamanit, Stan i Alamanit, Serpentinschutt, 1400 m ü.d.M.”, 15/07/1928, F. Markgraf \& W. Pieper, no. 1688; "Nord-Albanien: Stammesgebiet Merdita, Östteil des Mal i Shenjit (Bajrak Oroshi), Qaf e Mshkallës am Fuß der Zepa, 1200 m ü.d.M.”, 24/07/1928, F. Markgraf \& W. Pieper, no. 1848. The selected neotype was collected in the locality to the east of Krujë and fits the original description of the species.

(=) A. balkanicum f. depressum Nyárády (1930: 394), syn. nov. $\equiv$ A. balkanicum var. depressum (Nyár.) Nyárády (1949: 157).

Neotype (designated here):-ALBANIA. "Prefettura di Dibër, Distretto di Mat, lungo la sterrata che sale da ovest al passo di Murrë (Qafë 


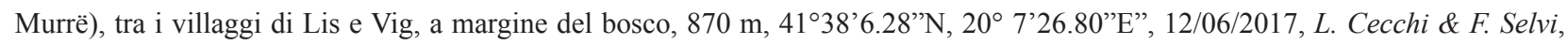
FI050830, FI!

The neotype is from the Lurë mountains, as mentioned in the original description (Nyárády 1930: 395): "Nord-Albanien: Stammesgebiet

Lurja, Kunora e Lurës, Qaf e Thëres (Südöstlich Kumbla [Kumbull]), Wiese, Serpentin, 1500 m ü. D. M.”, 21/07/1928, F. Markgraf

\& W. Pieper, no. 1810. The other original collection was: "Mittel-Albanien: Gur i Topit (Quellgebiet des Shkumbins), SW.-Seite,

Serpentinschutt westl. Qaf e Shalësit, 1500 m ü. D. M.”, 27/06/1928, F. Markgraf \& W. Pieper, no. 1540.

(=) A. balkanicum var. calvescens Nyárády (1949: 158), syn. nov.

Neotype (designated here):-ALBANIA. "prefettura di Kukës, distretto di Tropojë, Fierzë, pietraia di serpentino e arbusteto basso lungo la strada presso il ponte sul lago omonimo, $220 \mathrm{~m}, 42^{\circ} 16^{\prime}$ '5.92”'N, 20 1’34.54”'E”, 12/07/2016, I. Bettarini, L. Cecchi, A. Coppi, C. Gonnelli, P. Meerts \& F. Selvi, FI050444, FI!

The original collection of this taxon was from the same area of the neotype designated here (lower Valbona valley close to Fierzë):

ALBANIA. "Unt. Valbone-Tal", sine die, sine coll., "Herb. Schütt Bremen" (not found in BREM).

(=) A. balkanicum f. microcarpum Nyárády (1949: 158), syn. nov.

Neotype (designated here):-ALBANIA. "prefettura di Durazzo (Durrës), distretto di Croia (Krujë), versante occidentale del Maja e Liqenit, pietraia serpentinosa sul primo tornante a gomito subito oltre il passo di Shtamës, $1010 \mathrm{~m}, 41^{\circ} 31$ '11.42”N, 1952’51.85”'E. Serpentino", 06/10/2017, I. Bettarini \& F. Selvi, FI052160, FI!

The original collections used to describe this taxon (syntypes) were: “Albania media: Kruja, Östl. der qaf e Shtamës, serp. 900 m”, sine die, F. Markgraf; "Matja, Qafa e Müreş", sine die, F. Markgraf.

(=) A. lurense Meyer (2011: 64), syn. nov. $\equiv$ O. lurensis (F.K.Mey.) Španiel, Al-Shehbaz, D.A.German \& Marhold in Španiel et al. (2015: 2485).

Holotype:-ALBANIA. “Lura, Kunora e Lures, ca. 1300 m”, 02/08/1959, F.K. Meyer, Flora Albanica no. 4627, JE00016685, JE!

Flowering stems $20-90 \mathrm{~cm}$, erect, robust. Sterile shoots at the base always present and more or less abundant, often forming densely leafy cushions. Basal leaves up to $25 \times 9 \mathrm{~mm}$, broadly spathulate and obtuse, greenish with scattered hairs above, white-silvery below for dense, overlapping hairs with 10-15 rays $0.3-0.6 \mathrm{~mm}$ across. Leaves on flowering stems numerous, narrowly oblong-spathulate, flat. Inflorescence broadly corymbose, dense, with branching of third and, more commonly, fourth level. Partial racemes usually short and dense, with up to 15 fruits. Fruiting pedicels erecto-patent, never flexuous. Sepals $2.2 \times 0.5-0.8 \mathrm{~mm}$. Petals $1.8-2.8 \mathrm{~mm}$. Style $0.8-1.0 \mathrm{~mm}$. Siliculae (2.5)3.5(4) $\times$ (1.6) $2.0(2.7) \mathrm{mm}$, narrowly to broadly elliptic, acute to subacute, usually symmetrical; valves not undulate when ripe, indistinctly veined; valves glabrous to glabrescent, ca. $0.2 \mathrm{~mm}$ across, 5-10 rayed. Seeds $2.0-2.2 \mathrm{~mm}$ long, including a wing of $0.4-05 \mathrm{~mm}$. Figs. 3C, 6D, 7D, 9.

Phenology. Flowering from late June to mid August, fruits ripening from the end of July to the first half of October (Fig. 4).

Chromosome number. 2n = 32+0-2B (Fig. 5F); plants from N (south of Gjegian, region of Püke, FI050443) and C Albania (east of Krujë, FI050442).

Distribution and ecology. Mainly on the outcrops of N and C Albania (Fig. 1; Appendix 1). It grows strictly on ultramafic rocks, from 220 to $1900 \mathrm{~m}$ a.s.1., both in anthropogenic sites, such as fields and pasturelands on shallow soil, and natural habitats such as rocky slopes, screes, stony and gravelly soils and mountain grasslands. Also present in Kosovo, Macedonia and N Greece.

Nickel accumulation. The lowest concentration was detected in plants from Fierzë, the highest in those from the Krujë region, with a difference of over $9000 \mu \mathrm{g} \mathrm{g}^{-1} \mathrm{dw}$ (Table 1).

Comments. This species was described based on a Baldacci's collection from Mt. Smolikas in N Greece, and interpreted as a hybrid between O. smolikana and O. muralis (Nyárády 1927). It was then included in O. muralis s.l. (Ball \& Dudley 1993, Jalas et al. 1996) or O. chalcidica, though it was stated that its identity remains uncertain (Hartvig 2002). Our Albanian collections, with clearly intermediate characters between $O$. smolikana subsp. glabra and $O$. chalcidica, match the description and type collection of $O$. decipiens and can be readily referred to this taxon. Its distinctness is supported by the stability of the diagnostic characters in large populations, which are widely distributed in $\mathrm{C}$ and $\mathrm{N}$ Albania. These are mostly found within the ranges of $O$. chalcidica and $O$. smolikana, at an intermediate altitude, and have likely resulted from extensive homoploid hybridization at the contact zone between populations of the latter two taxa, both $2 \mathrm{n}=32$. The same process has likely occurred in the area of Mt. Smolikas, where O. smolikana subsp. smolikana and O. chalcidica occur at different altitudes (Hartvig 2002). The separate status of $O$. decipiens is supported by the various later names that were published for it based on material from the mountains of C Albania, such as A. kosaninum var. obovatifolium, A. balkanicum s.l. and A. lurense. To date, the conspecificity of these taxa was not recognized due to the difficulty in the study of type collections, scarcity of herbarium material and field 


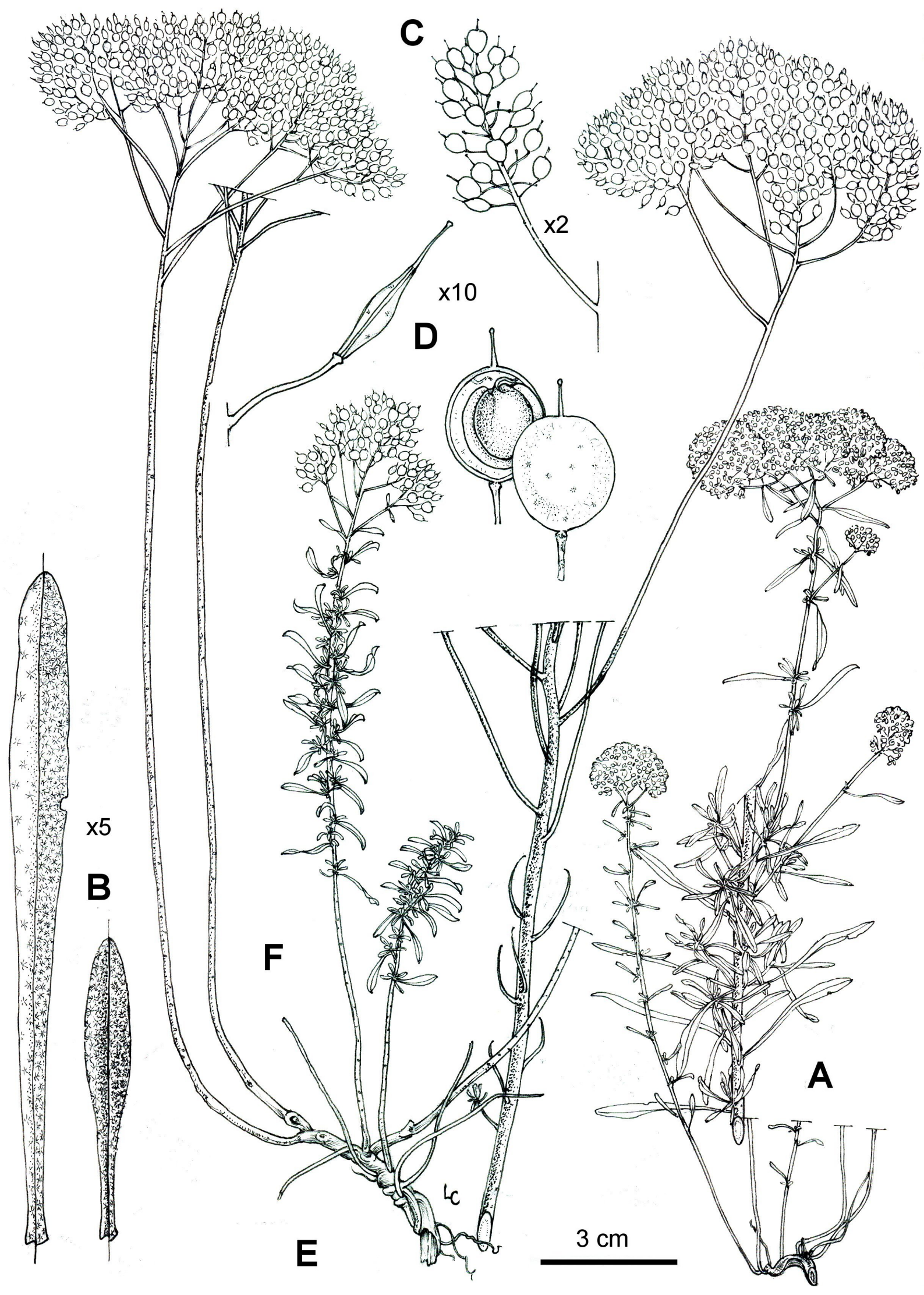

FIGURE 8. O. chalcidica: A, F) habit (flowering and fruiting specimens of different stature); B) cauline leaves of flowering (left) and sterile (right) shoots, showing their upper and lower surface on the left and on the right, respectively; C) lateral fruiting raceme; D) silicle in lateral, inner and outer view. Original drawing by L. Cecchi (based on FI050844 and FI050882). 


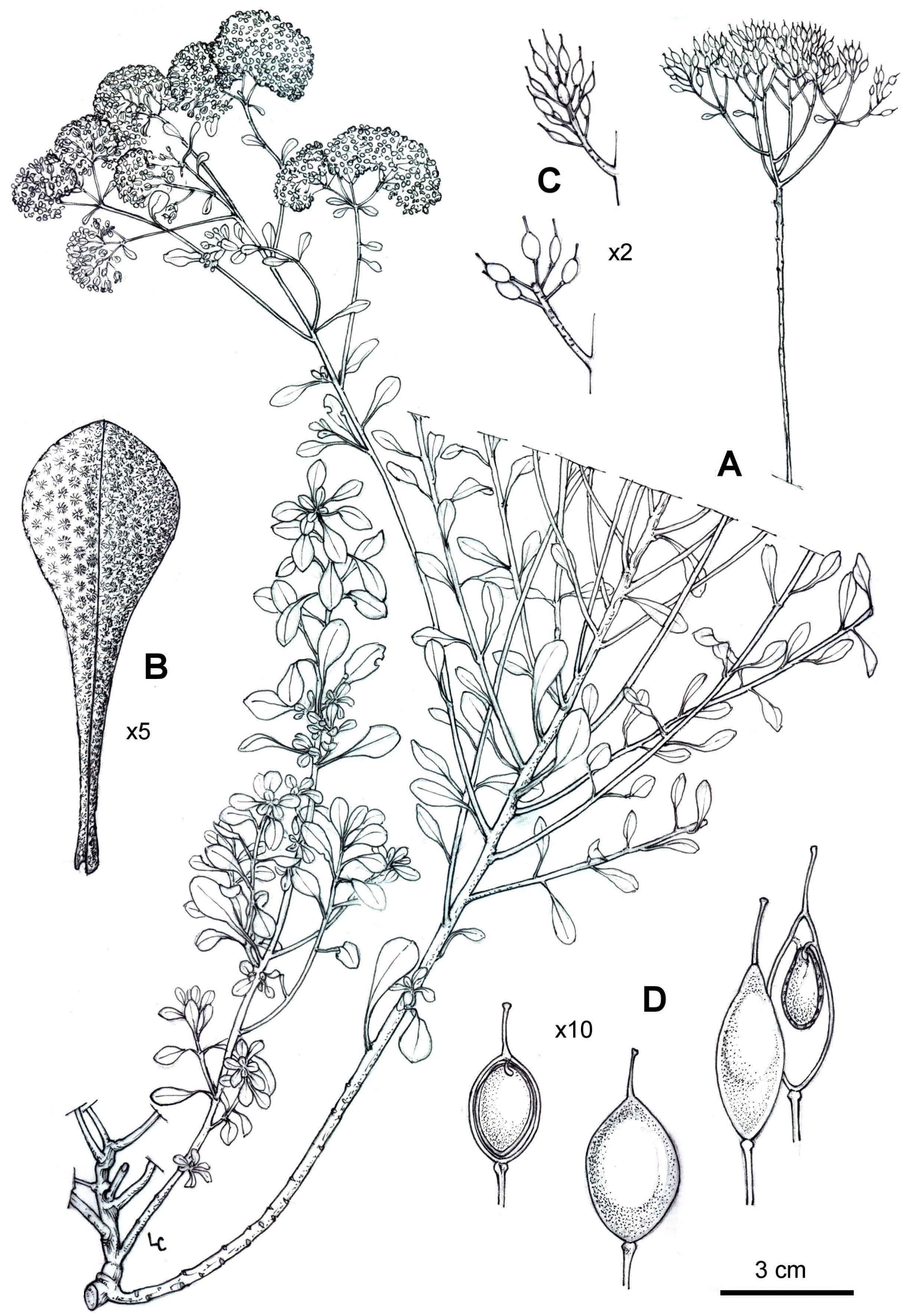

FIGURE 9. O. decipiens. A) habit (flowering specimen and fruiting shoot); B) leaf of sterile shoot, showing its upper (on the left) and lower surface (right); C) lateral fruiting racemes; D) closed and open silicles of different size and shape. Original drawing by L. Cecchi (based on FI050442 and FI052160). 


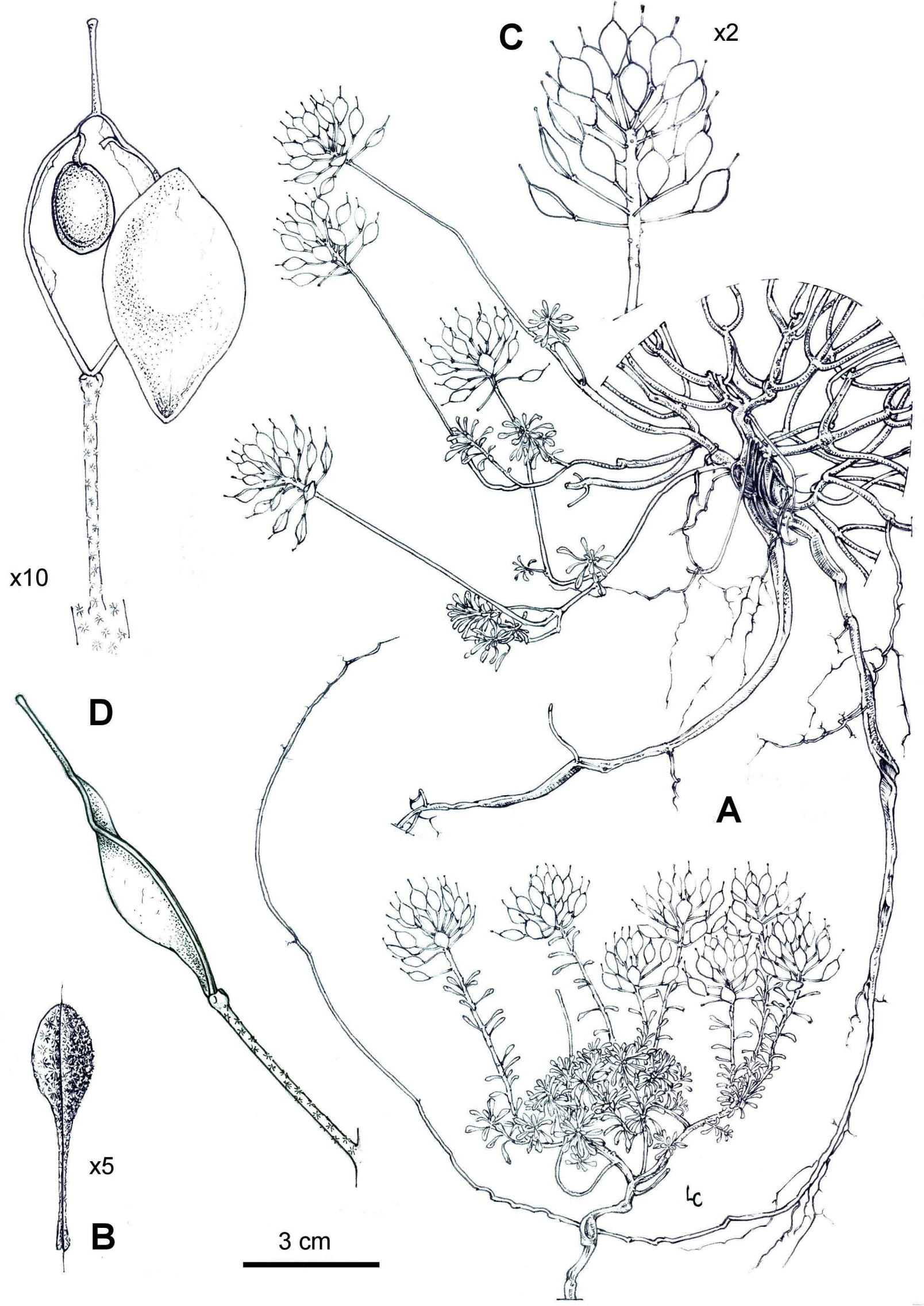

FIGURE 10. O. moravensis. A) habit (fruiting specimens); B) leaf of sterile shoot, showing its upper (left) and lower surface (right); C) lateral fruiting raceme; D) silicle in lateral, inner and outer view. Original drawing by L. Cecchi (based on the FI050441 and FI050828). 


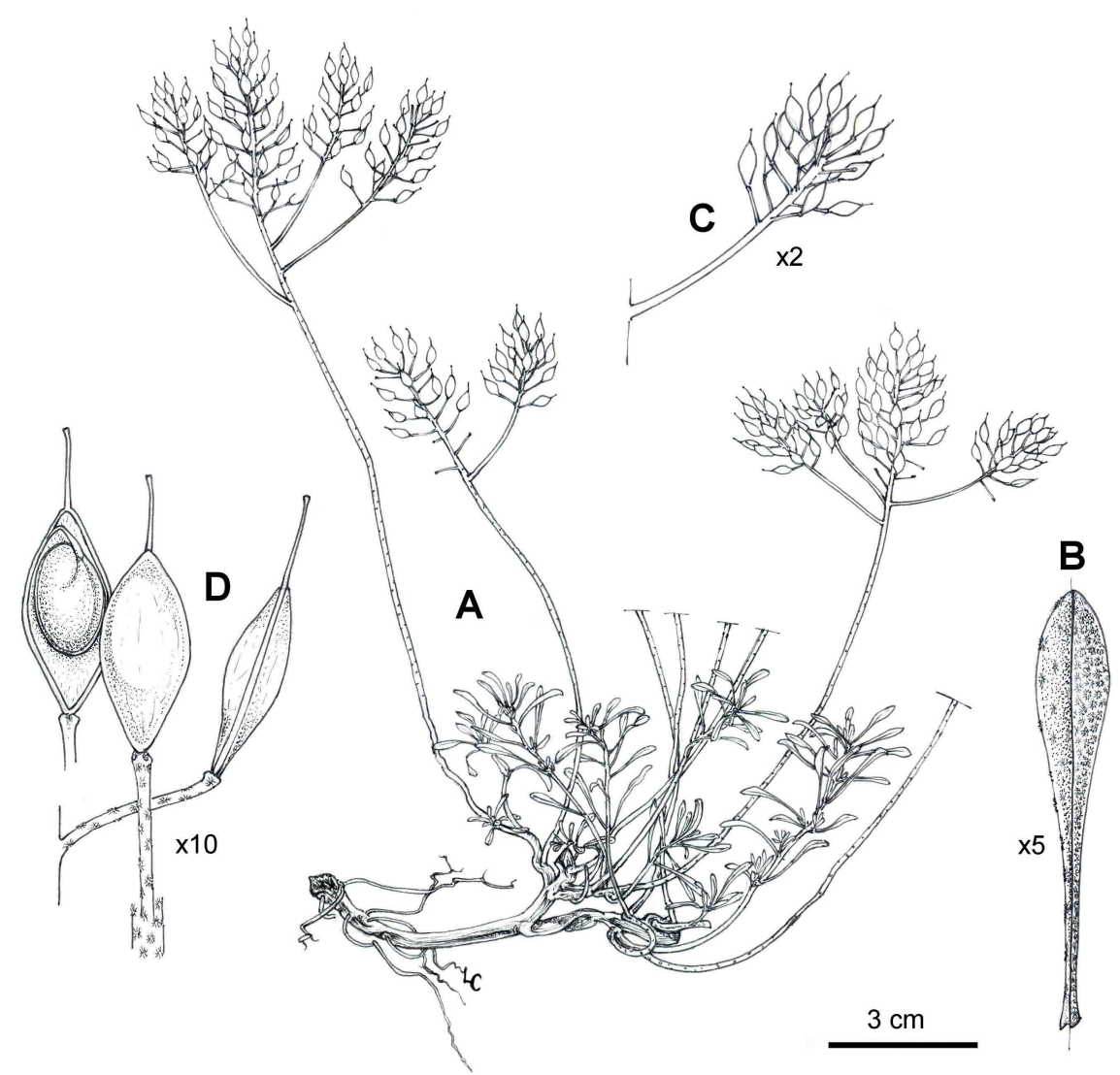

FIGURE 11. O. rigida. A) habit (fruiting specimen); B) leaf of sterile shoot, showing its upper (left) and lower surface (right); C) lateral fruiting raceme; D) silicle in lateral, inner and outer view. Original drawing by L. Cecchi (based on the neotype specimen, FI050434).

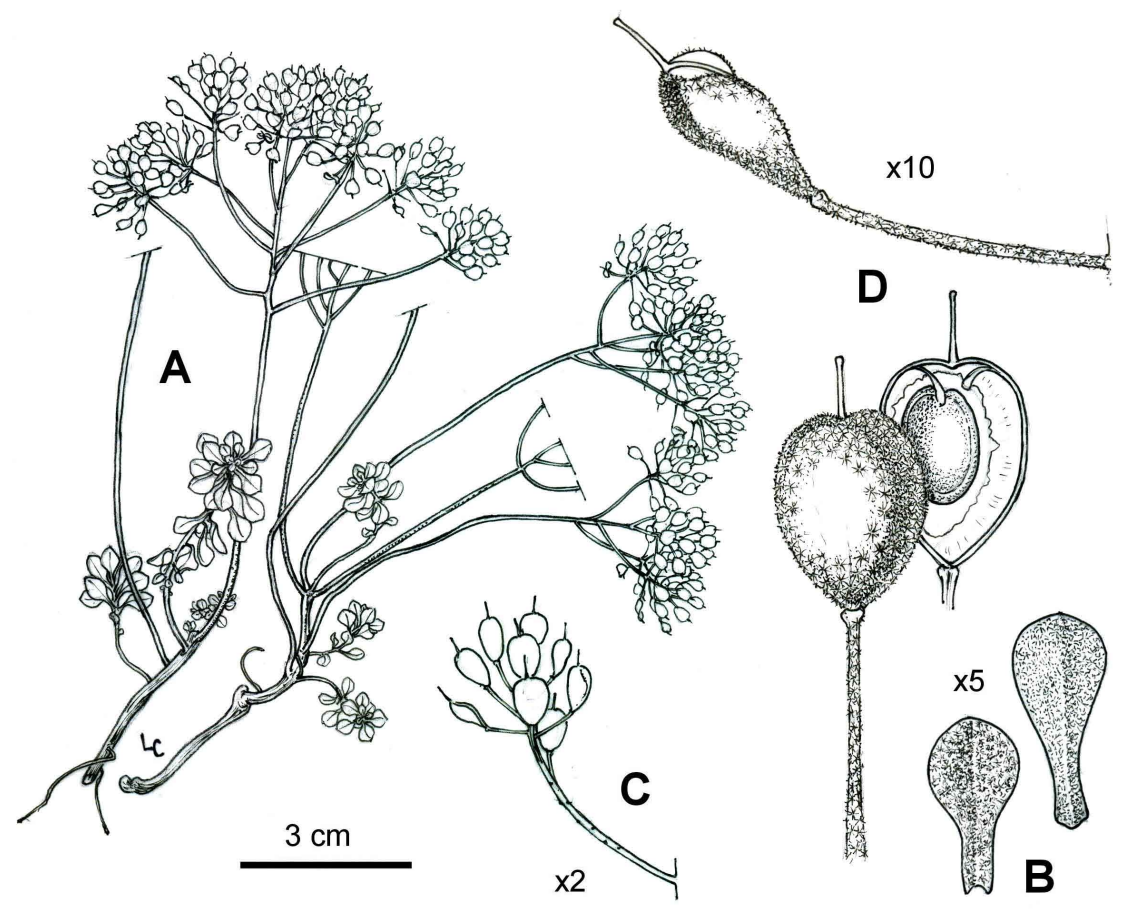

FIGURE 12. O. sibirica. A) habit (fruiting specimens); B) leaves of sterile shoot from above (left) and below (right); C) lateral fruiting raceme; D) silicle in lateral, inner and outer view. Original drawing by L. Cecchi (based on the isotype of Alyssum suffrutescens var. epirotum BM000750156). 


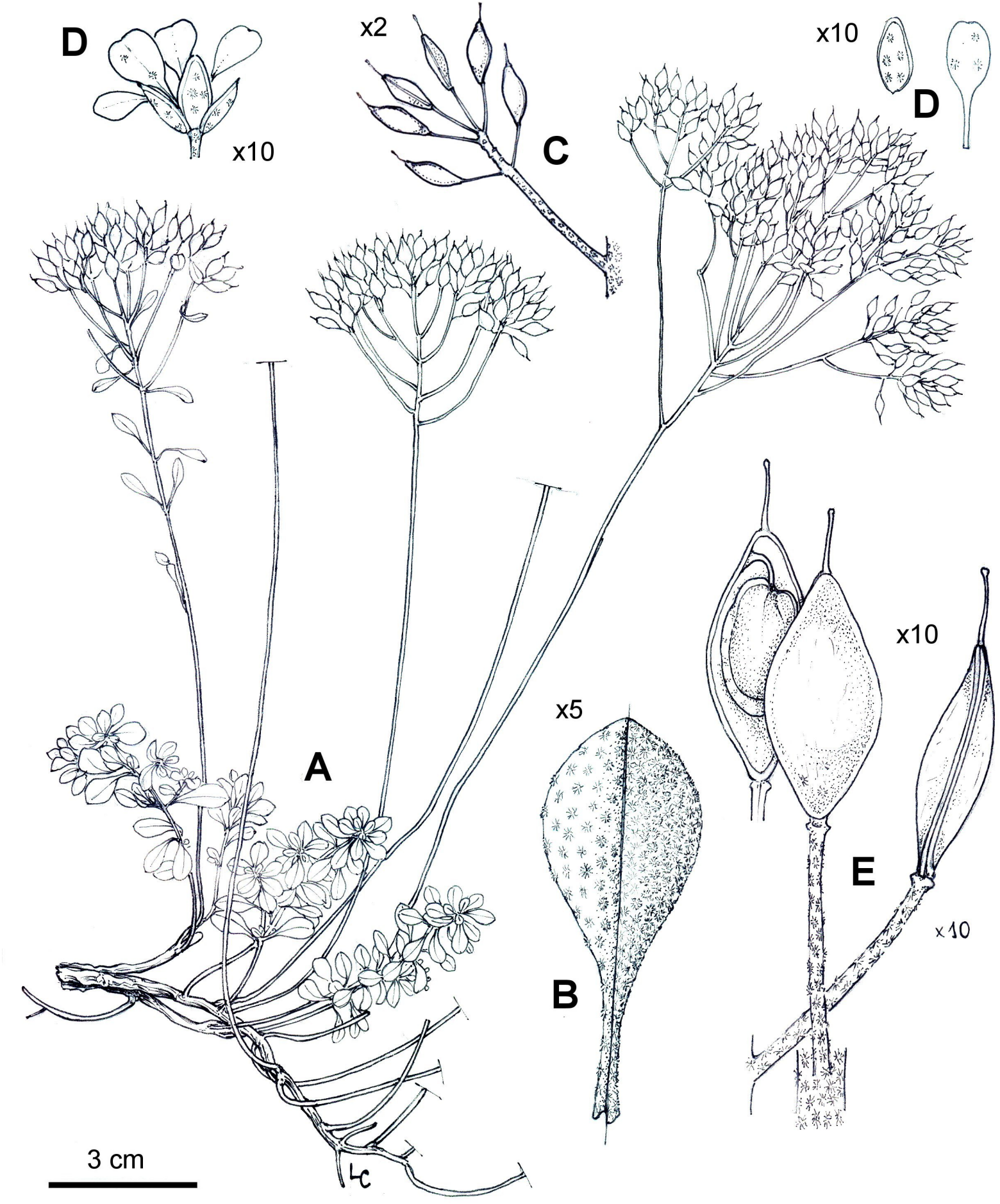

FIGURE 13. O. smolikana subsp. glabra. A) habit (fruiting specimen); B) leaf of sterile shoot, showing its upper (on the left) and lower surface (right); C) lateral fruiting raceme; D) flower in lateral view, with isolated sepal and petal; E) silicle in lateral, inner and outer view. Original drawing by L. Cecchi (based on FI050431 and FI050835).

observations. This applies especially to A. balkanicum (mentioned as a synonym of A. bertolonii subsp. scutarinum in Ball \& Dudley 1993, and Jalas et al. 1996), whose type material was lost during $2^{\text {nd }}$ World War. Major distinguishing characters of $A$. decipiens are the tall and robust habit, the numerous stems arising from base, each with numerous sterile shoots bearing large, spathulate leaves with white-silvery abaxial surface; the cauline leaves are also larger and denser (Fig. 9). In addition, flowering and fruiting in this species are considerably delayed compared with both $O$. chalcidica and $O$. smolikana subsp. glabra, regardless of altitude (Fig. 4). Plants of $O$. decipiens from higher altitudes with lower stems and habit similar to that of the latter species (described as A. balkanicum f. depressum) differ by the later flowering and the silicle morphology (see key to species). 
(三) A. smolikanum subsp. moravense F.K.Mey.

Holotype:-ALBANIA. "Korça, Mali i Moravës, bei Drenova, ca. 1100-1200 m, Serpentin”, 12/09/1961, F. K. Meyer, Flora Albanica no. 6144, JE00016687, JE!

Isotype:-JE00016688, JE!

Cushion-like habit with erect-ascending flowering stems, $8-15(18) \mathrm{cm}$. Sterile shoots at the base numerous, branched and densely leafy. Basal leaves $4-8 \times 1.2-1.6 \mathrm{~mm}$, narrowly obovate-spathulate, blade well distinct from petiole, slightly folded, subacute, greenish on upper surface, whitish-silvery below for overlapping hairs with 15-22 rays, ca. $0.5 \mathrm{~mm}$ across. Cauline leaves similar to the basal ones. Flowering stems straight, terminating into short, simple (very rarely 1-branched), racemes, remaining compact in fruit, with 10-18 silicles. Fruiting pedicels patent, rigid. Sepals ca. $1.8 \mathrm{~mm}$, stellate-pubescent. Petals ca. $2.5 \mathrm{~mm}$ long. Style ca. $1.5 \mathrm{~mm}$. Siliculae $4.8-5.5 \times 2.8-3.2 \mathrm{~mm}$, elliptic and almond-shaped, subacute at apex, symmetrical; valves often somewhat undulate, veined, glabrous. Seeds ca. $1.6 \mathrm{~mm}$, including a very narrow wing up to ca. $0.15 \mathrm{~mm}$. Figs. 3D, 6F, 7F, 10.

Phenology. Flowering from April to early June, fruit ripening rarely extending to mid July (Fig. 4).

Chromosome number. 2n = 16 (Fig. 5C); plants from the area of Voskopoje, west of Korça (FI050441).

Distribution and ecology. Endemic to the serpentine massifs on the Korça region in E Albania (Morave, Voskopoje, Devolli). It grows only in primary, undisturbed habitats, such as rocky slopes, gravels and stony ground, always on serpentine, from 800 to $1500 \mathrm{~m}$ a.s.1. It is allopatric with respect to both $O$. smolikana subsp. serpentinicola and $O$. rigida (Fig. 1; Appendix 1).

Nickel accumulation. Ni levels in this species were variable but always above $5000 \mu \mathrm{g} \mathrm{g}^{-1} \mathrm{dw}$ (Table 1).

Comments. Originally described as a subspecies of A. smolikanum from a single collection, based on the glabrous silicles (Meyer 2011). This character, however, is diagnostic with respect to Greek O. smolikana subsp. smolikana (with stellate-pubescent silicles), but not to Albanian subsp. glabra which also has glabrous fruits (Figs. 6E, F). Nevertheless, the specific status of this taxon is justified by a combination of diagnostic traits that can be readily appreciated on native populations and complete herbarium material, such as the smaller and narrowly spathulate-lanceolate basal leaves, the short and simple racemes, the patent fruit pedicels and the seeds with narrower wing. As in other species, the latter character is associated with the diploid chromosome complement (Cecchi et al. 2013), whereas typical $O$. smolikana is tetraploid with distinctly winged seeds (see above). This species also differs from O. rigida by the lower, cushion-like habit, the smaller leaves with white silvery lower surface, the simple racemes and the larger silicles with slightly undulate valves (Fig. 11).

5. O. rigida (Nyárády 1928: 101) L.Cecchi \& Selvi, comb. nov.

(三) A. bertolonii subsp. rigidum Nyár. $\equiv$ A. rigidum (Nyár.) Nyárády (1930: 393).

Neotype (designated here):-ALBANIA. "prefettura di Elbasan, distretto di Elbasan, a sud-est di Elbasan, pendii serpentinosi sopra l'abitato di Shushicë, 220 m, 41 5'55.35”N, 20 8'57.25”'E”, 14/07/2016, I. Bettarini, L. Cecchi, A. Coppi \& F. Selvi, FI050434, FI!

Isoneotypes:-B!, K!, Herb. Cecchi no. 3321!

The neotype selected here is from near the same locality of the original collection, formerly in B: "Mittel-Albanien: Mali Sphatit südlich Elbasan, in offenem Serpentinschutt bei Leshan und Mali Shüshices massenhaft, 800 m. ü. M.”, 01/06/1924, F. Markgraf.

Erect and somewhat rigid flowering stems, $10-20 \mathrm{~cm}$. Sterile shoots at the base always present, branched and densely leafy. Basal leaves 12-18(22) $\times 1.3-2.0 \mathrm{~mm}$, narrowly spathulate-lanceolate, tapering into petiole, blade often gutterlike folded along the midvein and arching, subacute, green with only scattered hairs on upper surface, greenish on lower surface for 2 layers of denser hairs with 12-24 rays, c. $0.25 \mathrm{~mm}$ across. Inflorescence corymbose, with rigid, broadly divaricated secondary racemes, the lateral ones with up to 15(2) fruits. Fruiting pedicels erecto-patent, rigid. Sepals $1.5-2.0 \times 0.7-1.0 \mathrm{~mm}$. Petals $22.8 \mathrm{~mm}$. Style ca. $1.5 \mathrm{~mm}$. Siliculae 4.5-5.0 $\times 2.4-2.9 \mathrm{~mm}$, almond-shaped, symmetrical; valves not undulate, indistinctly veined, glabrous. Seeds ca. 1.8 long, including a very narrow wing up to ca. $0.15 \mathrm{~mm}$. Figs. $3 \mathrm{E}, 6 \mathrm{H}, 7 \mathrm{H}, 11$.

Phenology. Flowering from April to early May, fruit ripening until late June (Fig. 4).

Chromosome number. $2 \mathrm{n}=16$ (Fig. 5B); plants from the type locality (Mt. Shpat, FI050434).

Distribution and ecology. Endemic to central Albania in the Shkumbin river valley and adjacent massifs in the 
districts of Elbasan and Librazhd (Shpat, Shebenik). It grows in primary, mostly undisturbed habitats, such as rocky slopes, gravels and stony ground, always on serpentine, from 200 to $1250 \mathrm{~m}$ a.s.l. (Fig. 1; Appendix 1).

Nickel accumulation. Ni levels in this species were variable but always above $7000 \mu \mathrm{g} \mathrm{g}^{-1} \mathrm{dw}$ (Table 1). The maximum concentration was detected in plants from Mt. Shebenik, while the lowest was in samples from the area of Mt. Shpat.

Comments. Originally described as a subspecies of the Italian endemic $O$. bertolonii (Desv.) Jord. \& Fourr.; the specific status of this taxon was correctly recognized two years later by Nyárády himself (1930). Major distinguishing characters are the lower habit, the denser and longer basal leaves on branched sterile shoots, greenish on both surfaces, the shorter and denser partial racemes and the larger silicules (Figs. 6H, 11). In addition, flowering and fruit ripening occur considerably earlier than in $O$. bertolonii. The interpretation of this taxon as a synonym of the latter (Ball \& Dudley 1993, Jalas et al. 1996) is due to a poor understanding of the species characters, since the short Latin diagnosis was the only available element after the destruction of the type material in B.

6. O. sibirica (Willdenow 1800: 465) Španiel, Al-Shehbaz, D.A.German \& Marhold in Španiel et al. (2015: 2486).

\section{( $\equiv)$ Alyssum sibiricum Willd.}

Lectotype (designated here):-_Sibiria", sine die, sine coll., B-W 11902-02-03, B-W!

The folder of A. sibiricum in Willdenow's herbarium contains three sheets, all annotated as “Alyssum lepidulum Nyár. ssp. genuinum Nyár." by Nyárády in 1932. The one selected here as lectotype is the only one showing the typical characters of $O$. sibirica as currently known, especially in the fruit. The two other specimens (B-W 11902-02-01, B-W!; B-W 11902-02-02, B-W!) are poorer and without well-developed fruits. A collection from Willdenow's herbarium currently kept in Halle (HAL0086103, HAL!) is also likely original material. The indication "Habitat in Sibiria" is written on the folder with the lectotype specimen and two additional collections; Nyárády, however, annotated that this plant does not grow in Siberia (Russia) but was most probably collected in Turkey.

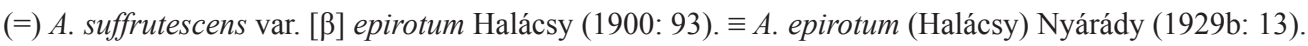

Lectotype (designated here):-ALBANIA. "In alveo fl. Sarandaporos ad Vomonero, distr. Ljaskovik", 03/07/1896, A. Baldacci, Iter Albanicum (Epiroticum) Quartum no. 101, WU0033153, WU!

Isolectotypes:-A00018590, A!; BM000750156, BM!; G00389273, G!; K000484621, K!; WU0067969, WU!; Z000004364, Z!].

The lectotype selected here was already indicated by Hartvig (2002: 222), though not formally typified. Among the several duplicates of the type collection, this specimen is the only one from Halácsy's herbarium bearing the label "Alyssum suffrutescens (Boiss.) $\beta$ epirotum" in his own handwriting.

Flowering stems numerous, ascending, up to $12 \mathrm{~cm}$, arising from a dense base of woody and tortuose vegetative shoots up to 3-10 cm long, bearing dense leaf rosettes. Lower leaves 4-8 $\times 1.5-6 \mathrm{~mm}$, orbicular-spathulate to broadly obovate, subacute, densely covered on both surfaces with whitish pubescence of overlapping, 16-22 rayed hairs, 0.5$0.8 \mathrm{~mm}$ across. Inflorescence broadly corymbose, with secondary branches only; partial racemes up to $5 \mathrm{~cm}$, bearing ca. 10-15 fruits crowded in their upper third. Sepals $1.5-2 \mathrm{~mm}$. Petals 2-2.5 mm. Style ca. $0.8 \mathrm{~mm}$. Siliculae ca. $3.5 \times$ $3 \mathrm{~mm}$, broadly obovate to obcordate (wider near apex), truncate to slightly retuse; valves asymmetrically inflated and S-shaped in cross-section, with 10-16-rayed dense stellate hairs, $0.35 \mathrm{~mm}$ across. Seeds $1.2-1.8 \mathrm{~mm}$, without or with very narrow wing. [Flower and trichome characters based on Greek material]. Fig. 12.

Phenology. Flowering from April to early June, ripening of fruits in June (Fig. 4).

Chromosome number. The Albanian plants remain unknown (no material available for karyological observations).

Distribution and ecology. The only confirmed collection of this species from the Albanian territory is the type locality of A. epirotum, i.e. the right bank of river Vjosë (Aoos) at the border with Greece (Fig. 1; Appendix 1). The collection was from the gravelly river bed, on non-serpentine soil.

Nickel accumulation. Unknown. O. sibirica is a facultative serpentinophyte and is possibly the only one that does not accumulate Ni when growing on serpentine soil (Reeves \& Adigüzel 2008, Cecchi et al. 2010).

Comments. Odontarrhena sibirica is commonly reported from Albania (Greuter et al. 1986, Ball \& Dudley 1993, Hartvig 2002, Marhold 2011) and sometimes even as widely distributed especially in the central and southern parts of the country (e.g. Jalas et al. 1996). However, we could not observe this plant during our field surveys, neither in the type locality of var. epirotum, and no herbarium material was found in the major European Herbaria. Hence, Baldacci's historical collection at the border with Greece is at present the only one that can be confirmed from Albania, while most other records are likely due to confusion with different taxa. 
(三) A. smolikanum f. glabrum Nyár. ex Markgraf.

Neotype (designated here):-Albanien, Lura, Kunora e Lures, ca. 2000 m, serpentin. 02/08/1959, F.K. Meyer, Flora Albanica no. 4680, JE00016686 (JE!). The original collection of f. glabrum, formerly in B, was "Nord Albanien, Stammesgebiet Lurja, Kunora e Lurës, Serpentinschutt, 1800 m ü d. M.”, 21/07/1928. Markgraf \& Pieper no. 1790”.

The type of $A$. serpentinicola is selected here to serve also as neotype of $O$. smolikana subsp. glabra because collected in the same locality, fully matching the original description of the latter taxon and clearly corresponding to it.

(三) A. serpentinicola Meyer (2011: 65), syn. nov. $\equiv$ O. serpentinicola (F.K.Mey.) Španiel, Al-Shehbaz, D.A.German \& Marhold in Španiel et al. (2015: 2486).

Holotype:-ALBANIA. "Lura, Kunora e Lures, ca. 2000 m, Serpentin. 02/08/1959, F.K. Meyer, Flora Albanica no. 4680 , JE00016686 (JE!).

Flowering stems up to (15)20-30 cm, erect-ascending. Sterile shoots at base numerous and much-branched, with rosette-like leaves 6-12(15) $\times 4-6 \mathrm{~mm}$, broadly spathulate to obovate-cuneate, obtuse, greenish with 1 layer of hairs above, whitish-silvery below for 2 layers of dense hairs with 10-18 rays, 0.3-0.6 mm across. Leaves of flowering stems spathulate, narrower. Inflorescence corymbose, dense, with secondary (rarely tertiary) branches. Partial racemes with (3) 8-15 flowers. Fruiting pedicels thick, erecto-patent, straight. Sepals $2.5-3.0 \mathrm{~mm}$. Petals $3.5 \mathrm{~mm}$. Style 1.5-2.0 $\mathrm{mm}$. Siliculae 4.9-5.6 × 2.8-3.0 mm, almond-shaped, symmetrical; valves pale green and slightly inflated when ripe, not undulate, indistinctly veined, glabrous or rarely with very sparse hairs near base. Seeds 2.- $2.4 \mathrm{~mm}$ long, including a wing of $0.4 \mathrm{~mm}$. Figs. 3F, 6E, 7E, 13.

Phenology. Flowering from May to June, fruit ripening from June to July (Fig. 4).

Chromosome number. $2 \mathrm{n}=32$ (Fig. 5G); our count on plants from Mt. Shebenik (FI050433) match a previous report for O. smolikana subsp. smolikana from N Greece (Contandriopoulos 1969).

Distribution and ecology. Endemic to Albania and restricted to the mountains of the central part of the country (Fig. 1). It grows in mountain grasslands and screes, pastures and rocky slopes, from 1100 to $2000 \mathrm{~m}$ a.s.l.

Nickel accumulation. Maximum Ni levels were determined in plants from Krastë (Bulqizë), which were nearly two times higher than those in samples from Shtamë pass east of Krujë (Table 1).

Comments. The presence of $O$. smolikana in Albania was originally indicated by the author of the species (Nyárády 1929b) based on a collection by N. Košanin from "Maja Ranns" (Maja Rauns, in the Lüre region) and supported by later authors (i.e. Greuter et al. 1986, Ball \& Dudley 1993, Jalas et al. 1996, Hartvig 2002). The Albanian populations differ from the typical Greek plants from by the glabrous silicles (Fig. 6E) and the earlier flowering and fruiting time, and were first described as f. glabrum (Nyárády 1930). More recently, the same taxon was described as $A$. serpentinicola (Meyer 2011), based on material from the same region (Lüre). Since the Albanian populations are not sufficiently distinct to be kept as a distinct species, the earlier epithet ("glabrum") is used here for the combination at the subspecies rank.

\section{Key to Albanian taxa of Odontarrhena}

1. Basal leaves obtuse at apex, orbicular-spathulate to broadly obovate, less than $1 \mathrm{~cm}$ long, densely covered on both surfaces with dense, whitish pubescence (more than one layer of trichomes); silicles obovate (wider in the upper half), their valves sharply asymmetrically inflated and S-shaped in cross-section; seeds unwinged or nearly so .................................................. sibirica

1. Basal leaves usually rounded at apex, variable in shape but usually more than $1 \mathrm{~cm}$ long, with upper surface green to greyish-green, not covered with dense whitish pubescence (a single layer of trichomes); silicles elliptical to orbicular, with maximum width near the middle, their valves more or less symmetrically inflated, not S-shaped in cross section; seeds winged or unwinged...............2

2. Silicle valves densely covered with stellate hairs.............................................................................................. albiflora

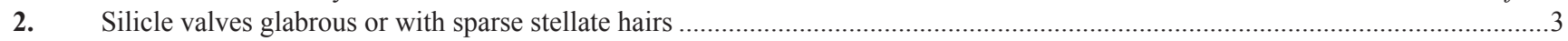

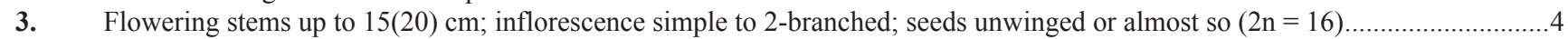

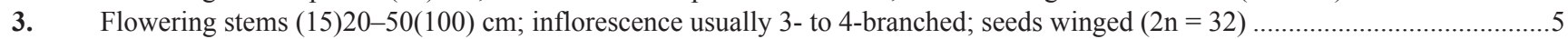

4. Basal leaves narrowly lanceolate, with indistinct petiole, up to $22 \mathrm{~mm}$ long; inflorescence a branched raceme; siliculae ca. $4 \mathrm{~mm}$, with flat valves ..............................................................................................................................................

4. Basal leaves obovate-spathulate, with distinct petiole, up to $12 \mathrm{~mm}$ long; inflorescence reduced to simple, terminal racemes; silicles up to $5.5 \mathrm{~mm}$, with slightly undulate valves............................................................................................ moravensis

5. Erect, with sterile shoots usually absent or few at flowering time and fertile stems branched in the upper quarter; leaves oblanceolate to narrowly spathulate, often incurved and gutter-folded, greenish to greyish below; lateral simple racemes with 20 fruits or more; pedicels thin, sometimes flexuous; silicles broadly elliptic to orbicular...... O. chalcidica 
5. Erect-ascending, cushion-like, much branched from the base, with numerous sterile shoots and fertile stems often crowded, usually branched between their upper third and the middle, or even below; leaves broadly obovate-spathulate to almost orbicular, flat, white-silvery below; lateral simple racemes with (3)5-10(15) fruits; pedicels relatively thick and rigid; silicles almond-shaped to broadly elliptic.....

6. Flowering stems up to $30 \mathrm{~cm}$; inflorescence 2- to (rarely) 3-branched; silicles always almond-shaped, usually completely glabrous, ca. 5-5.5 mm long; flowering from May to July, fruiting from June to August ..................................... smolikana subsp. glabra

6. Flowering stems up to 50(90) $\mathrm{cm}$; inflorescence 3- to (usually) 4-branched; silicles almond-shaped to broadly elliptic, sparsely hairy to glabrescent, ca. 2.5-4 mm long; flowering from June to August, fruiting from August to October .................... decipiens

\section{FINAL REMARKS}

A robust taxonomy of metallophytes is crucial for any other type of scientific study or practical use of these plants. In addition, they represent a unique biological resource whose conservation depends on available information about their diversity, distribution and ecological requirements. According to Whiting et al. (2004), metallophytes and their habitats are seriously threatened at a global scale by different types of human disturbance. Good taxonomic skills and geobotanical explorations of poorly known areas with metal-rich soils are crucial to this purpose. Albania is one of these areas, despite its position at the heart of the Mediterranean basin and the outstanding botanical interest of its vast serpentine outcrops (Vangjeli et al. 2000, Stefanović et al. 2003).

Field exploration and study of natural populations was necessary to bring order into the confused taxonomy of Odontarrhena in this country. Overall, we provide evidence that the taxa native to this territory and the names to be applied for them are largely not the same of those reported in the recent literature. Reduction to synonymy of $O$. markgrafii and $O$. bertolonii subsp. scutarina is here advocated along with the reappraisal of three taxa that have been neglected since the time of their description, i.e. O. rigida, O. smolikana subsp. glabra and O. decipiens. The latter was recently described as A. lurense by Meyer (2011), who correctly recognized the specific status of this probably hybridogenous taxon though disregarding the valid name already available for it. Similar considerations apply to the endemic O. smolikana subsp. glabra, that was also described again as A. serpentinicola (Meyer 2011) despite its close affinity to typical subsp. smolikana in $\mathrm{N}$ Greece. Also endemic is $O$. rigida, that was incorrectly synonymized by previous authors with the Italian endemic $O$. bertolonii, possibly due to the lack of types and other herbarium material in the major European herbaria. The Albanian endemic component is enriched by two taxa distributed in the southeast of the country, O. moravensis and O. albiflora, both previously known only from the type collection (Meyer 2011). While the latter seems to have an extremely narrow distribution and preference for limestone rocks, the former is the vicariant of $O$. rigida on the serpentine massifs of the East (Morave, Voskopoje and Devolli). Much wider distribution, even outside Albania, have $O$. chalcidica and $O$. sibirica. Unlike reported in most of the recent literature, the latter species is very rare in Albania, neither confirmed by recent and reliable observations nor by herbarium specimens other than the single collection by Baldacci from the extreme south of the country. The group of O. muralis s.1. has long represented a challenge for taxonomists, because of the great phenotypic plasticity of populations and the largely continuous variation between them (Strid 2016). However, correlation between a set of morphological characters, ecological preferences and distribution patterns supports $O$. chalcidica as a distinct species from typical $O$. muralis, which is mainly a non-serpentinophyte with a more continental distribution, absent from Albania. In this country, $O$. chalcidica is the most common and widely distributed species, sometimes found also on non-serpentine soils, and usually forming large populations in anthropogenic habitats. Ecological and phenotypic plasticity are clearly associated in these populations, some of whose local variants have been variously referred to a number of taxa with little taxonomic value, such as $O$. markgrafii and $O$. bertolonii subsp. scutarina (Cecchi et al. 2010). The more recently described $O$. elatior also falls within the range of variation of $O$. chalcidica, despite the slightly divergent habit and morphology of basal leaves suggest that the populations with this morphotype can be the result of introgression with sympatric $O$. moravensis.

Phenotypic plasticity and capacity to colonize anthropogenic habitats seems associated with polyploidy in $O$. chalcidica, $O$. decipiens and also $O$. smolikana, while the two vicariant diploids $O$. moravensis and $O$. rigida are much less variable and always restricted to primary undisturbed habitats. Nickel concentrations in all accessions and species analysed here were well above the hyperaccumulation threshold of $1000 \mu \mathrm{g} \cdot \mathrm{g}^{-1}$ leaf dw, including O. albiflora from limestone rocks, and in the ranges of values reported in previous papers for Balkan and Serbian populations of Odontarrhena (Shallari et al. 1998, Tumi et al. 2012, Bani et al. 2015). However, more precise comparisons between species are not possible due to the uncertain identity of the plant material used in these previous works. Our data suggest 
no clear differences between diploid and tetraploid taxa in shoot metal concentrations, but the wide infraspecific variation across populations requires experiments in controlled conditions to better understand their real accumulation capacity. At present, the high Ni levels and ecological plasticity of $O$. chalcidica and $O$. decipiens make of them promising candidates for phytoremediation and phytomining applications.

\section{ACKNOWLEDGEMENTS}

Authors wish to acknowledge the curators of the mentioned herbaria for allowing consultation of material or providing relevant information; Hartmut H. Hilger (Berlin), for checking literature and herbarium collections in B; Cristina Salvatici and Laura Vivona (Florence) for technical assistance, Arne Strid (Copenhagen), and Lefter Kashta (Tirana) for discussion. Anonymous reviewers provided useful comments on the original manuscript. This research was conducted in the framework of Agronickel, a FACCE SURPLUS project supported by ERA-NET Cofund.

\section{LITERATURE CITED}

Baker, A.J.M., Ernst, W.H.O., van der Ent, A., Malaisse, F. \& Ginocchio, R. (2010) Metallophytes: The unique biological resource, its ecology and conservational status in Europe, central Africa and Latin America. In: Batty, L.C. \& Hallberg, K.H. (Eds.) Ecology of industrial pollution. Cambridge University Press, Cambridge, 740 pp.

https://doi.org/10.1017/CBO9780511805561.003

Ball, P.W. \& Dudley, T.R. (1993) Alyssum L. In: Tutin, T.G., Heywood, V.H., Burges, N.A, Moore, D.M., Valentine, D.H., Walters, S.M., \& Webb, D.A. (Eds.) Flora Europaea, 2nd edition, 1. Cambridge University Press, Cambridge, pp. 359-369.

Bani, A., Imeri, A., Echevarria, G., Pavlova, D., Reeves, R.R., Morel, J.L. \& Sulçe, S. (2013) Nickel hyperaccumulation in the serpentine flora of Albania. Fresenius Environmental Bulletin 22: 1792-1801.

https://doi.org/10.1656/045.016.0528

Bani, A., Shallari, S., Echevarria, G., Gjeta, E., Mullai, A., Naqellari, P. \& Meço, M. (2017) Field trip Guide: Ultramafic Areas of the south-eastern of Albania. $9^{\text {th }}$ International Conference on Serpentine Ecology, Tirana, $34 \mathrm{pp}$.

Brooks, R.R. (1980) Accumulation of Nickel by terrestrial plants. In: Nriagu, J.O. (Ed.) Nickel in the Environment. Wiley \& Sons, New York, pp. 407-456.

https://doi.org/10.1002/food.19820260991/full

Brooks, R.R. (1987) Serpentine and its vegetation. Dioscorides Press, Portland, 454 pp.

Cecchi, L. (2011) A reappraisal of Phyllolepidum (Brassicaceae), a neglected genus of the European flora, and its relationships in tribe Alysseae. Plant Biosystems 145:818-831.

https://doi.org/10.1080/11263504.2011.580789

Cecchi, L., Gabbrielli, R., Arnetoli, M., Gonnelli, C., Hasko, A \& Selvi, F. (2010) Evolutionary lineages of nickel hyperaccumulation and systematics in European Alysseae (Brassicaceae): evidence from nrDNA sequence data. Annals of Botany 106: 751-767. https://doi.org/10.1093/aob/mcq162

Cecchi, L., Colzi, I., Coppi, A., Gonnelli, C. \& Selvi, F. (2013) Diversity and biogeography of Ni-hyperaccumulators of Alyssum section Odontarrhena (Brassicaceae) in the central western Mediterranean: evidence from karyology, morphology and DNA sequence data. Botanical journal of the Linnaean Society 173: 269-289. https://doi.org/10.1111/boj.12084

Chaney, R.L., Angle, J.S., McIntosh, M.S., Reeves, R.D., Li, Y.M., Brewer, E.P., Chen, K.Y., Roseberg, R.J., Perner, H., Synkowski, E.C., Broadhurst, C.L., Wang, S. \& Baker, A.J. (2005) Using hyperaccumulator plants to phytoextract soil Ni and Cd. Zeitschrift für Naturforschung C 60: 190-198.

Contandriopoulos, J. (1969) Contribution à l'étude cytotaxinomique des Alysseae Adams de Grèce. Bulletin de la Société botanique de Genève 79: 313-334.

https://doi.org/10.5169/seals-55541

Dudley, T.R. (1964a) Studies in Alyssum: near Eastern representatives and their allies, I. Journal of the Arnold Arboretum 45: 57-100. Available from: https://www.biodiversitylibrary.org/item/33621\#page/61/mode/1up (accessed 28 May 2018)

Dudley, T.R. (1964b) Synopsis of the genus Alyssum. Journal of the Arnold Arboretum 45: 359-373. Available from: https://www. biodiversitylibrary.org/item/33621\#page/362/mode/1up (accessed 28 May 2018) 
Greuter, W., Burdet, H.M. \& Long, G. (1986) Med-Checklist. A critical inventory of vascular plants of the circum-mediterranean countries 3. Dicotyledones (Convolvulaceae-Labiatae). Conservatoire et Jardin Botaniques de la Ville de Genève, Geneva \& Berlin, cxxix + $395 \mathrm{pp}$.

Halácsy, E. von. (1900) Conspectus florae Graecae 1 (1). Lipsia [Leipzig]: Sumptibus Guilelmi Engelmann. https://doi.org/10.5962/bhl.title.9919

Hayek von, A. (1927) Prodromus florae Peninsulae Balcanicae 1. Pteridophyta, Gymnospermae, Dicotyledoneae (Apetalae et Choripetalae). Repertorium Specierum Novarum Regni Vegetabilis. Centralblatt für Sammlung und Veroffentlichung von Einzeldiagnosen neuer Pflanzen. Beihefte 30: 961-1193.

Hartvig, P. (2002) Alyssum. In: Strid, A. \& Tan, K. (Eds.) Flora Hellenica 2. Gantner Verlag, Ruggell, pp 199-224.

Hegi, G. (1986) Illustrierte Flora von Mittel-Europa, 3rd rev. ed., 4 (1). Verlag, Berlin-Hamburg, 70 pp.

Ingle, R.A., Mugford, S.T., Rees, J.D., Campbell, M.M. \& Smith, J.A.C. (2005) Constitutively high expression of the histidine biosynthetic pathway contributes to nickel tolerance in hyperaccumulator plants. The Plant Cell 17: 2089-2106. https://doi.org/10.1105/tpc.104.030577

Jalas, J \& Suominen, J. (1996) Atlas Florae Europeae 11. The Committee for Mapping the Flora of Europe and Societas Biologica Fennica Vanamo, Krämer, Helsinki, 310 pp.

Janka, V. de. (1872) Plantarum novarum turcicarum breviarium. Oesterreichische Botanische Zeitschrift 22: 174-182. https://doi.org/10.1007/BF01644772

Koch, W.D.J. (1836) Synopsis florae germanicae et helveticae. F. Wilmans, Francofurti ad Moenum [Frankfurt am Main], 102 pp. https://doi.org/10.5962/bhl.title.6629

Krämer, U., Cotter-Howells, J.D., Charnock, J.M., Baker, A.J.M. \& Smith, J.A.C. (1996) Free histidine as a metal chelator in plants that accumulate nickel. Nature 379: 635-638. https://doi.org/10.1038/379635a0

Ledebour, K.F. von, 1830. Icones plantarum novarum vel imperfecte cognitarum floram Rossicam, imprimis Altaicam, illustrantes. 2. I. Deubner, Riga, 30 pp. +100 figs. https://doi.org/10.5962/bhl.title.46626

Ledebour, K.F. von, Bunge, A. von \& Meyer, C.A. (1831) Flora Altaica 3. G. Reimeri, Berolinum [Berlin], viii + 368 pp. https://doi.org/10.5962/bhl.title.6618

Li, Y., Feng, Y., Lv, G., Liu, B. \& Qi, A. (2015) The phylogeny of Alyssum (Brassicaceae) inferred from molecular data. Nordic Journal of Botany 33: 715-721. https://doi.org/10.1111/njb.00588

Linnaeus, C. (1753) Species plantarum 2. Impensis Laurentii Salvii, Holmia [Copenhagen], 639 [561-1200] + 31 [final, not numbered pages of index, addenda and errata] $\mathrm{pp}$. https://doi.org/10.5962/bhl.title.669

Marhold, K. (2011) Brassicaceae. In: Euro +Med Plantbase - the information resource for Euro-Mediterranean plant diversity. Available from: http://www.emplantbase.org/home.html (accessed 13 December 2017)

Markgraf, F. (1926) Bemerkenswerte neue Pflanzenarten aus Albanien. Berichte der Deutschen Botanischen Gesellschaft 44: $420-432$. Available from: http://onlinelibrary.wiley.com/doi/10.1111/j.1438-8677.1926.tb00989.x/abstract (accessed 28 May 2018)

Markgraf, F. (1931) Pflanzen aus Albanien 1928. Denkschriften der Kaiserlichen Akademie der Wissenschaften, Wien. MathematischNaturwissenschaftliche Klasse 102: 317-360. Available from: https://www.zobodat.at/stable/pdf/DAKW_102_0317-0360.pdf (accessed 28 May 2018)

McNeill, J., Barrie, F.R., Buck, W.R., Demoulin, V., Greuter, W., Hawksworth, D.L., Herendeen, P.S., Knapp, S., Marhold, K., Prado, J., Prud'homme van Reine, W.F., Smith, J.H., Wiersema, J.H. \& Turland, N.J. (Eds.) (2012) International Code of Nomenclature for algae, fungi, and plants (Melbourne Code) adopted by the Eighteenth International Botanical Congress Melbourne, Australia, July 2011. Regnum Vegetabile 154: i-xxx, 1-240. [monographic volume]

Mengoni, A., Baker, A.J.M., Bazzicalupo, M., Reeves, R.D., Adigüzel, N., Chianni, E., Galardi, F., Gabbrielli, R. \& Gonnelli, C. (2003) Evolutionary dynamics of nickel hyperaccumulation in Alyssum revealed by ITS nrDNA analysis. New Phytologist 159: 691-699. https://doi.org/10.1046/j.1469-8137.2003.00837.x

Meyer, F.K. (2011) Beiträge zur Flora von Albanien. Haussknechtia Beiheft 15: 1-220.

Micevski, K. (1994) Die Sect. Odontarrhena (C.A. Meyer) Koch der gattung Alyssum L. (Cruciferae) in der Flora der Republik Makedonien. Prilozi, Oddelenie za Bioloshki i Meditsinski Nauki Makedonska Akademija na Naukite i Umetnostite 15: 41-58.

Nkrumah, P.N., Baker, A.J.M., Chaney, R.L., Erskine, P.D., Echevarria, G., Morel, J.L. \& van der Ent, A. (2016) Current status and challenges in developing nickel phytomining: an agronomic perspective. Plant \& Soil 406: 55-69.

https://doi.org/10.1007/s11104-016-2859-4

Novák, F. (1927) Ad florae Serbiae cognitionem additamentum alterum. Preslia 5: 65-137. 
Nyárády, E.J. (1928) [“1927”] Studiu preliminar asupra unor specii de Alyssum din sectia Odontarrhena. Vorstudium über einige Arten der Section Odontarrhena der Gattung Alyssum. Buletinul Gradinii Botanice si al Muzeului Botanic dela Universitatea din Cluj 7 (1-4): 3-51, 65-160.

Nyárády, E.J. (1929a) [“1928”] Studiu preliminar asupra unor specii de Alyssum din secţia Odontarrhena. Vorstudium über einige Arten der Section Odontarrhena der Gattung Alyssum (Forsetzung). Buletinul Gradinii Botanice si al Muzeului Botanic dela Universitatea $\operatorname{din}$ Cluj 8 (2-4): 152-156.

Nyárády, E.J. (1929b) Studiu preliminar asupra unor specii de Alyssum din secţia Odontarrhena. Vorstudium über einige Arten der Section Odontarrhena der Gattung Alyssum (Schluss). Buletinul Gradinii Botanice si al Muzeului Botanic dela Universitatea din Cluj 9 (1-2): $1-68$.

Nyárády, E.J. (1930) Neue Beiträge zur Kenntnis der Balkanischen Alyssum-Arten. Repertorium Specierum Novarum Regni Vegetabilis. Centralblatt für Sammlung und Veroffentlichung von Einzeldiagnosen neuer Pflanzen 27: 392-395.

Nyárády, E.J. (1932) [“1931”] Les formes vraies et fausses de l'espèce Alyssum alpestre L. Buletinul Gradinii Botanice si al Muzeului Botanic dela Universitatea din Cluj 9 (3-4): 69-78.

Nyárády, E.J. (1939) [“1938”] Neue Alyssum Arten und Formen aus der Odontarrhena-Sektion. Buletinul Gradinii Botanice si al Muzeului Botanic dela Universitatea din Cluj 18 (1-4): 82-99.

Nyárády, E.J. (1949) Synopsis specierum, variationum et formatum sectionis Odontarrhenae generis Alyssum. Analele Academiei Republicii Populare Române, Sectiunea de Stiinte Geologice, Geografice si Biologice, Analele, seria A 1 (3): 1-133.

Palomino, M., Kennedy, P.G. \& Simms, E.L. (2007) Nickel hyperaccumulation as an anti-herbivore trait: considering the role of tolerance to damage. Plant \& Soil 293: 189-195. https://doi.org/10.1007/s11104-007-9236-2

Reeves, R.D, , Brooks, R.R. \& Dudley, T.R. (1983) Uptake of nickel by species of Alyssum, Bornmuellera and other genera of Old World Tribus Alysseae. Taxon 32: 184-192. https://doi.org/10.2307/1221970

Reeves, R.D. \& Adigüzel, N. (2008) The nickel hyperaccumulating plants of the serpentines of Turkey and adjacent areas: a review with new data. Turkish Journal of Biology 32: 143-153.

Rešetnik, I., Satovic, Z., Schneeweiss, G.M. \& Liber, Z. (2013) Phylogenetic relationships in Brassicaceae tribe Alysseae inferred from nuclear ribosomal and chloroplast DNA sequence data. Molecular Phylogenetics and Evolution 69: 772-786. https://doi.org/10.1016/j.ympev.2013.06.026

Robertson,A.H.F. (2012) Late Palaeozoic-Cenozoic tectonic development of Greece and Albania in the context of alternative reconstructions of Tethys in the Eastern Mediterranean region. International Geology Review 54: 373-454. https://doi.org/10.1080/00206814.2010.543791

Robinson, B.H., Chiarucci, A., Brooks, R.R., Petit, D., Kirkman, J.H. \& Gregg, P.E.H. (1997) The nickel hyperaccumulator plant Alyssum bertolonii as a potential agent for phytoremediation and phytomining of nickel. Journal of Geochemical Exploration 59: 75-86. https://doi.org/10.1016/S0375-6742(97)00010-1

Rusterholz, H.P., Aydin, D. \& Bauer, B. (2012) Population structure and genetic diversity of relict populations of Alyssum montanum on limestone cliffs in the Northern Swiss Jura mountains. Alpine Botany 122: 109-117. Available from: https://ink.springer.com/ content/pdf/10.1007/s00035-012-0105-0.pdf (accessed 28 May 2018)

Selvi, F., Carrari, E., Colzi, I., Coppi, A. \& Gonnelli, C. (2017) Responses of serpentine plants to pine invasion: vegetation diversity and nickel accumulation in species with contrasting adaptive strategies. Science of the Total Environment 595: 72-80. https://doi.org/10.1016/j.scitotenv.2017.03.249

Shallari, S., Schwartz, C, Hasko, A. \& Morel, J.L. (1998) Heavy metals in soils and plants of 316 serpentine and industrial sites of Albania. Science of the Total Environment 209:133-142. https://doi.org/10.1016/S0048-9697(98)80104-6

Španiel, S., Kempa, M., Salmerón-Sánchez, E., Fuertes-Aguilar, J., Francisco Mota, J., Al-Shehbaz, I.A., German, D.A., Olšavská, K., Šingliarová, B., Zozomová-Lihová, J. \& Marhold, K. (2015) AlyBase — database of names, chromosome numbers, and ploidy levels of Alysseae (Brassicaceae), with a new generic concept of the tribe. Plant Systematics and Evolution 301: 2463-2491. https://doi.org/10.1007/s00606-015-1257-3

Stefanović, V., Tan, K. \& Iatrou, G. (2003) Distribution of the endemic Balkan flora on serpentine I.-Obligate serpentine endemics. Plant Systematics and Evolution 242: 149-170. https://doi.org/10.1007/s00606-003-0044-8

Strid, A. (2016) Atlas of the Aegean Flora. Englera 33: 149-153. https://doi.org/10.1007/s00606-003-0044-8

Tatić, B. \& Veljović, V. (1992) Distribution of serpentinized massives on the Balkan peninsula and their ecology. In: Roberts, B.A. \& Proctor, J. (Eds.) The ecology of areas with serpentinized rocks. A world view. Kluwer Academic Publishers, Dordrecht, pp. 
$199-215$.

https://doi.org/10.1007/978-94-011-3722-5_8

Tumi, A.F., Mihailović, N., Gajić, B.A., Niketić, M. \& Tomović, G. (2012) Comparative study of hyperaccumulation of nickel by Alyssum murale. Populations from the ultramafics of Serbia. Polish Journal of Environmental Studies 21: 1855-1866.

https://doi.org/10.1007/s11104-007-9245-1

Vangjeli, J. (2015) Excursion Flora of Albania. Koeltz Botanical Books, Oberreifenberg, 661 pp.

Vangjeli, J., Ruci, B., Mullaj, A. \& Xhulaj, M. (2000) Flora e vegetazione in Albania. In: Marchiori, S., De Castro, F. \& Myrta, A. (Eds.) La cooperazione italo-albanese per la valorizzazione della biodiversità. Cahiers Options Méditerranéennes 53: 51-66.

Verbruggen, N., Hermans, C. \& Schat, H. (2009) Molecular mechanisms of metal hyperaccumulation in plants. New Phytologist 181: $759-776$.

https://doi.org/10.1111/j.1469-8137.2008.02748.x

Warwick, S.I., Sauder, C.A. \& Al-Shehbaz, I.A. (2008) Phylogenetic relationships in the tribe Alysseae (Brassicaceae) based on nuclear ribosomal ITS DNA sequences. Botany 86: 315-336.

https://doi.org/10.1139/B08-013

Whiting, S.N, Reeves, R.D. \& Richards, D., Johnson, M.S., Cooke, J.A., Malaisse, F., Paton, A., Smith, J.A.C., Angle, J.S., Chaney, R.L., Ginocchio, R., Jaffré, T., Johns, R., McIntyre, T., Purvis, O.W., Salt, D.E., Schat, H., Zhao, F.J. \& Baker, A.J.M. (2004) Research priorities for conservation of metallophyte biodiversity and their potential for restoration and site remediation. Restoration Ecology 12: $106-116$ https://doi.org/10.1111/j.1061-2971.2004.00367.x

Willdenow, C.L. (1800) Species plantarum, ed. 4, 3 (1). Impensis G. C. Nauk, Berolinum [Berlin], 847 pp. https://doi.org/10.5962/bhl.title.727

Wójcik, M., Gonnelli, C., Selvi, F., Dresler, S., Rostański, A. \& Vangronsveld, J. (2017) Metallophytes of serpentine and calamine soils-Their unique ecophysiology and potential for phytoremediation. In: Cuypers, A. \& Vangronsveld, J. (Eds.) Phytoremediation. Advances in Botanical Research 83: 1-42. [monographic volume] https://doi.org/10.1016/bs.abr.2016.12.002

\section{Appendix 1. List of examined herbarium specimens (other than types).}

Odontarrhena albiflora. Korçë: "Distretto di Coriza (Korçë), pareti rocciose calcaree sulle pendici occidentali del Mali i Thatë, sopra il villaggio di Shëngjergji (o Gurbardhë), 950 m, 4045’26.06”'N, 2049'59.29”'E”, 08/06/2017, L. Cecchi \& F. Selvi, FI050840, FI050841, FI!_Ibidem, 07/10/2017, I. Bettarini \& F. Selvi, FI052166, FI! O. chalcidica. Berat: "Secus viam e pago Bogdan [Bogdan i Sipërm] ed Perišnjake [Perisnake] sub m. Tomor" 10/08/1892, $A$. Baldacci, Iter Albanicum $1892 n^{\circ}$ 181, FI050873, FI!; K! [as Alyssum murale f. reichenbachianum]. Dibër: "Ulzë", 30/09/1959, X. Qosja, TIR! [as Alyssum murale]_"'Shkopet rresh 150 m. serpentinë”, 02/10/1959, X. Qosja, TIR! [as Alyssum markgrafii]_-"Qafë Shtamë, 1000-1200 m. flysh”, 17/09/1961, I. Mitrushi \& D. Shuqja, TIR! [as Alyssum

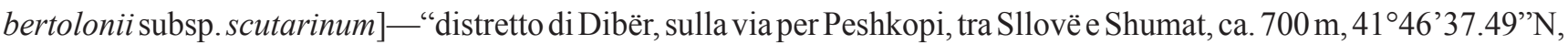
20²3'10.39”'E”, 13/07/2016, I. Bettarini, L. Cecchi, A. Coppi \& F. Selvi, FI050427, FI! - “distretto di Dibër, sbancate

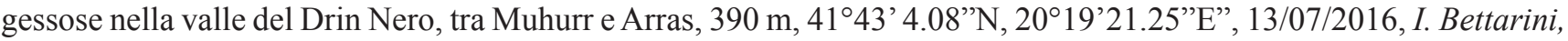
L. Cecchi, A. Coppi \& F. Selvi, FI050426, FI! - "distretto di Dibër, sbancate calcaree $4 \mathrm{~km}$ a sud di Shupenze, sulla strada per Librazhd, 740 m, 4129'52.62”N, 20²6' 1.28”'E”, 13/07/2016, I. Bettarini, L. Cecchi, A. Coppi \& F. Selvi, FI050425, FI! - "Distretto di Mat, lungo la sterrata che da Burrel sale al passo di Shtamës, poco sopra Komsi, su serpentino, 430 m, 4134'45.20”N, 1957'19.62"E”, 12/06/2017, L. Cecchi \& F. Selvi, FI050845, FI! - "Distretto di

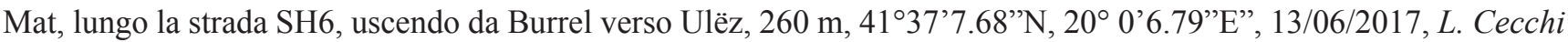
\& F. Selvi, FI050842, FI! Durrës: "distretto di Croia (Krujë), versante occidentale del Maja e Liqenit, ruderali su serpentino scendendo dal passo di Shtamës, 930 m, 41³1'3.00”N, 1952'49.62”'E”, 18/07/2016, I. Bettarini, L. Cecchi, A. Coppi \& F. Selvi, FI050419, FI! Elbasan: "Gjinar 800 m. serp.”, 12/06/1960, X. Qosja, TIR! [as Alyssum bertolonii subsp. scutarinum] - "Vasjan rreth $1200 \mathrm{~m}$. flysh", 17/06/1960, X. Qosja, TIR! [as Alyssum murale] —"distretto di Librazhd, Perrënjas, incolti, substrato ofiolitico", 11/06/2005, A. Hasko, n³334 / 05.09, FI050874, FI!-“distr. Librazhd, incolti di natura ofiolitica presso Perrënjas", 24/07/2007, L. Cecchi, A. Coppi, R. Gabbrielli \& A. Hasko, $n^{\circ} 07.21$, FI050878, FI050883, FI!- “distr. Librazhd, lungo la strada per Pogradeč, su serpentino", 24/07/2007, L. Cecchi, A. Coppi, R. Gabbrielli \& A. Hasko, $n^{\circ} 07.22$, FI050881, FI050884, FI!-“"distretto di Librazhd (Cermenike), depositi misti calcareo-ofiolitici nella valle del torrente affluente dello Shkumbinit, a margine di incolti poco fuori 
l'abitato di Librazhd", 02/06/2009, F. Bartolini, L. Cecchi, S. Lepore \& C. Paoletti, FI050872, FI! - “distretto di Librazhd, rocce e detriti calcarei lungo la strada tra Perrënjas e Pogradeč (pendici del Gur i Pishkashit), al passo tra il bacino dello Shkumbinit e la conca del lago di Ohrid", 02/06/2009, F. Bartolini, L. Cecchi, S. Lepore \& C. Paoletti, FI050538, FI! - "ELBASAN—Shebenik-Jablanice National Park—Trabisht: përr Zulli i Stebleves / Jurinea sp. Community, ril. R 11 (447); 1000-1200 m. a.s.l. WGS84 UTM 34N455 4580", 05/06/2013, M. De Sanctis, Herbarium Albanicum n. 18484, RO-HG! [as Alyssum murale] — "distretto di Elbasan, a sud-est di Elbasan, pendii serpentinosi sopra l'abitato di Shushicë, 220 m, 41 5'55.35”N, 20 8'57.25"E”, 14/07/2016, I. Bettarini, L. Cecchi, A. Coppi \& F. Selvi, FI050423, FI! - “distretto di Librazhd, monte Shebenik, a ca. $1300 \mathrm{~m}$ tra Sutaj e Skënderbej, 41 9'14.08”N, 20³2'18.60"E”, 15/07/2016, I. Bettarini, L. Cecchi, A. Coppi \& F. Selvi, FI050428, FI! - "Distretto di Librazhd, lungo la strada tra Elbasan e Librazhd nella valle dello Shkumbin, circa $11 \mathrm{~km}$ a est-nord-est dal margine orientale del capoluogo, rocce ofiolitiche all'imbocco di una strada sterrata secondaria subito dopo il ponte sul fiume, $220 \mathrm{~m}$, $41^{\circ} 10^{\prime} 58.12$ ”N, 2016'27.74”E”, 08/06/2017, L. Cecchi \& F. Selvi, FI050843, FI! - "Distretto di Librazhd, monte

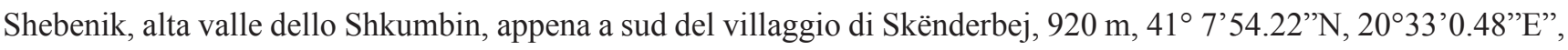
10/06/2017, L. Cecchi \& F. Selvi, FI050844, FI! - "Distretto di Librazhd, monte Shebenik, lungo la strada tra Përrenjas e Rrajcë. Incolti ruderali su serpentino.", 06/10/2017, I. Bettarini \& F. Selvi, FI052164, FI! Fier: "Lushnjë—Libofsh [Libofshë] aluvionale", 09/1954, M. Demiri, TIR! [as Alyssum bertolonii subsp. scutarinum] — "Kokël—Bratili Ura e Zallit të Shënepremte rresh 400 m. flysh”, 07/05/1960, M. Demiri \& E. Palihuyi, TIR! [as Alyssum bertolonii subsp. scutarinum] — "Kokël—Bratila ura e zallit Shënepremte", 07/05/1960, I. Mitrushi \& Zgjani, TIR! [as Alyssum murale]. Gjirokastër: "Gjirokastër", 1952, X. Qosja, TIR! [as Alyssum murale]. Kukës: “(HS), pendici occidentali del monte Paštrik, non lontano da Krumë. Gariga su serpentino, ca. 900 m”, 26/06/2006, L. Cecchi, A. Coppi \& F. Selvi, FI050846, FI! - “distretto di Has, pietraia serpentinosa lungo la strada tra Krumë e Kukës, nei pressi di Tobli, 720 m, 42 7'7.18”N, 20²0'50.53”"E”, 12/07/2016, I. Bettarini, L. Cecchi, A. Coppi, C. Gonnelli, P. Meerts \& F. Selvi, FI050422, FI! Korça: "Moskopolë (Voskopoj), $4500 \mathrm{ft}$, bare serpentine slopes, abundant", 20/08/1935, A. H. G. Alston \& N. Y. Sandwith, $n^{\circ} 2563[B], \mathrm{K}$ ! [as Alyssum markgrafii] — "sekundäre Vegetation in Eichenwaldresten. Qafa Thanes an der alban. Grenze (westl.Ochrida.See)”, 05/07/1938, F. Lemperg, $n^{\circ} 758$, K! [as Alyssum markgrafii] —“Mborjë”, 17/06/1952, N. Lako, TIR! [as Alyssum murale] — "Me shumicë rrazë fushes zë Korçë bri fshatrave Dishnicë, Barç , Mborjë, Drenovë, Boboshticë", 18/06/1952, M. Demiri, TIR! [as Alyssum murale] — "Progër (Bilisht) 800 m. flysh", 02/08/1953, M. Demiri, TIR! [as Alyssum murale] — "Bjll me pishe Manastir (Voskopojë)", 12/07/1954, M. Demiri, TIR! [as Alyssum murale]—Ibidem, 02/08/1954, M. Demiri, TIR! [as Alyssum murale]—"Shtyllë 1200-1800 m flysh", 06/07/1959, E. Palihuyi, TIR! [as Alyssum murale]_"Mali i Moravë, Drenovë, 1100-1300 m serp.”, 15/09/1961, E. Kongjika, TIR! [as Alyssum murale]_"QQaf'e Thanës rreth 900 m. flysh”, 28/06/1967, X. Qosja, TIR! [as Alyssum bertolonii]"Bitincka", 10/08/2004, A. Hasko, $n^{\circ} 04.01$, FI050875, FI!- “distretto di Pogradeč, presso il lago di Ohrid non lontano da Pogradeč, incolti, substrato ofiolitico", 10/08/2004, A. Hasko, n04.02, FI050849, FI!-Ibidem, 2005, A. Hasko, $n^{\circ}$ 05.10, FI050877, FI! - “distr. di Pogradeč, depositi serpentinosi presso le sponde del lago di Ohrid (Ocrida), nei pressi di Piskupat", 24/07/2007, L. Cecchi, A. Coppi, R. Gabbrielli \& A. Hasko, $n^{\circ} 07.23$, FI050882, FI050885, FI!"distretto di Pogradec, Pogradec, ruderali lungo la sterrata che sale alla cava di calcare all'ingresso nord-occidentale del paese, 800 m, 4054'49.86”N, 20³8'15.97”E”, 16/07/2016, I. Bettarini, L. Cecchi, A. Coppi \& F. Selvi, FI050416, FI!- “distretto di Coriza (Korçë), Moscopolis (Voskopoje), pietraia serpentinosa ca. 3,3 km a sud del paese, $1450 \mathrm{~m}$, 40³5’58.56”'N, 20³5’33.78”'E”, 16/07/2016, I. Bettarini, L. Cecchi, A. Coppi \& F. Selvi, FI050415, FI!-“distretto di Kolonjë, vallecola umida con depositi serpentinosi sulla via da Erseke Leskovik, poco oltre Barmash, $820 \mathrm{~m}$, 40¹6’22.01'N, 20³6’30.60”'E”, 17/07/2016, I. Bettarini, L. Cecchi, A. Coppi \& F. Selvi, FI050417, FI! - “Distretto di Coriza (Korçë), pendici nord-occidentali del monte Moravë sopra il villaggio di Drenovë, lungo la sterrata nella valle del torrente che attraversa il paese, rocce di serpentino, $1020 \mathrm{~m}, 40^{\circ} 34^{\prime} 43.84$ "N, 2047'46.13" ${ }^{\circ}$ ", 09/06/2017, $L$. Cecchi \& F. Selvi, FI050838, FI! [Odontarrhena elatior] — "Distretto di Coriza (Korçë), media valle del Devoll, lungo la strada da Maliq, ca. $2 \mathrm{~km}$ a valle di Lozhan, 4042'50.45”N, 20³1'33.72”'E, $680 \mathrm{~m}$. Serpentino.", 07/10/2017, I. Bettarini \& F. Selvi, FI052169, FI057170, FI! — "Distretto di Coriza (Korçë) [al confine con quello di Gramsh], media valle del Devoll, lungo la strada tra Moglicë e Bratilë, 4044'10.35’N, 20²0'4.83”E, ca. 500 m. Rupi serpentinose.", 07/10/2017, I. Bettarini \& F. Selvi, FI052167, FI! — "Distretto di Coriza (Korçë), pendici nord-occidentali del monte Moravë sopra il villaggio di Drenovë, lungo la sterrata nella valle del torrente che attraversa il paese, $40^{\circ} 34^{\prime} 43.84^{\prime \prime} \mathrm{N}$, 2047'46.13”E, 1020 m. Rocce di serpentino.", 07/10/2017, I. Bettarini \& F. Selvi, FI052165, FI!-“"Distretto di Gramsh, media valle del Devoll, lungo strada presso Bratilë, ca. 530 m.”, 07/10/2017, I. Bettarini \& F. Selvi, FI052162, FI! Lezhë: "On Mountain sides above Mamaras [Mamurras] near Laç, $1200 \mathrm{ft}$. Limestone Rock.", 13/06/1936, R. V. Pennington, $n^{\circ} 262$, K! [as Alyssum markgrafii]—“Rubik, miniera di Cu”, 12/06/2005, A. Hasko, n³355 / 05.08, FI050876, FI! Shkodër: "Guri i Zi, afer fabukes trellore, serpentinë”, 05/07/1996, Ruci \& Mullaj, TIR! [as Alyssum 
bertolonii] — "monte Grande Bardanjolt, a est della città di Scutari. Gariga su serpentino, ca. 80 m”, 23/06/2006, L. Cecchi, A. Coppi \& F. Selvi, FI050880, FI! - “distretto di Scutari (Shkodër), serpentini lungo la strada tra Scutari e Pukë, nei pressi di Vau-Dejës", 11/07/2016, I. Bettarini, A. Coppi, F. Selvi, FI050418, FI!—-"distretto di Scutari (Shkodër), serpentini del monte Bardanjolt, tra Scutari e Renc", 11/07/2016, I. Bettarini, A. Coppi, F. Selvi, FI050420, FI!-Ibidem, 11/07/2016, I. Bettarini, A. Coppi, F. Selvi, FI050421, FI! Vlorë: "Kodrat e Rrogozhinës 200 m. flysh?”, 08/06/1950, M. Demiri \& E. Palihuyi, TIR! [as Alyssum bertolonii subsp. scutarinum]—"Vergo", 05/06/1951, $N$. Lako, TIR! [as Alyssum murale]. O. decipiens. "[illegible], 1700 m", 20/07/2007, sine collectore, $n^{\circ} 07.24$, FI050847, FI050848, FI050870, FI050871, FI! Dibër: "Fushë-Lurë, buzë proit të Madh 1025 m. lardësi serpentinë”, 09/08/1949, K. Paparisto, TIR! [as Alyssum bertolonii subsp. scutarinum] — "Burel (German) rreth 600 m. serpentinë", 29/05/1959, X. Qosja, TIR! [as Alyssum bertolonii subsp. scutarinum]_-"Stacion Martanesh 1600 m, serpentinë, 1750 m", 23/06/1969, X. Qosja, TIR! [as Alyssum bertolonii subsp. scutarinum] —“Bulqiza, Fusha e e Torviollit [...]", 31/07/1973, X. B. Wang \& A. Lu, $n^{\circ} 443$, PE01002573 [as Alyssum murale], PE! - "Lurë, kodra e hurdhës në zezë, serpentinë, 1750 m”, 10/07/1976, J. Vangjeli, TIR! [as Alyssum bertolonii]_"Distretto di Bulqizë, lungo la SH6 tra Fushë Bulqizë e Bulqizë, pascoli e scarpate stradali, su serpentino, $750 \mathrm{~m}, 41^{\circ} 30^{\prime} 24.66^{\prime \prime} \mathrm{N}, 20^{\circ} 14^{\prime} 46.61^{\prime \prime} \mathrm{E}^{\prime}, 11 / 06 / 2017$, L. Cecchi \& F. Selvi, FI050832, FI! - "Distretto di Bulqizë, erbosi, pascoli e rocce serpentinose attorno al conoide alluvionale sopra al villaggio di Qyteti i Ri, presso Bulqizë, 1090 m, 41³0'53.70”N, 20¹2'46.26”'E”, 11/06/2017, L. Cecchi \& F. Selvi, FI050834, FI! - "Distretto di Mat, lungo la sterrata che sale da ovest al passo di Murrë (Qafë Murrë), tra i villaggi di Lis e Vig, a margine del bosco, 870 m, 4138'6.28'N, 20 7’26.80”'E”, 12/06/2017, L. Cecchi \& F. Selvi, FI050829, FI050868, FI! - "Distretto di Bulqizë, pascoli e rocce serpentinose verso il limite superiore della faggeta, lungo il sentiero che sale nella valle sopra al villaggio di Qyteti i Ri, presso Bulqizë, 1570 m, 41 31'32.08'N, 20¹3'17.35"E”, 13/06/2017, L. Cecchi \& F. Selvi, FI050833, FI! - "Distretto di Mat, versante orientale del Maja e Liqenit, alta valle del Mat, appena oltre il passo di Shtamës, 1150 m, 4131'31.94”N, 1954'7.49”'E. Serpentino.", 05/10/2017, I. Bettarini \& F. Selvi, FI052163, FI! Shkodër. "Ganjol [Ganjolle]", 26/06/1950, N. Lako, TIR! [as Alyssum bertolonii subsp. scutarinum] - "distretto di Pukë, Pukë, pendio serpentinoso lungo la strada per Gjegjan, 3-4 km a sud del paese, 510 m, 4154'29.34”N, 1959'51.24"E”, 11/07/2016, L. Cecchi, C. Gonnelli \& P. Meerts, FI050443, FI!-“"distretto di Pukë, pendio serpentinoso 5 km oltre Pukë, sulla strada per Fushë Arrëz, 940 m, 42 2'8.37'N, 1955'44.85"E", 12/07/2016, I. Bettarini, L. Cecchi, A. Coppi, C. Gonnelli, P. Meerts \& F. Selvi, FI050445, FI! Kukës. "distretto di Tropojë, Fierzë, pietraia di serpentino e basso arbusteto, lungo la strada presso il ponte sul lago omonimo, $220 \mathrm{~m}$, 42¹6' 5.92”N, 20 1'34.54"E”, 12/07/2016, I. Bettarini, L. Cecchi, A. Coppi, C. Gonnelli, P. Meerts \& F. Selvi, FI050444, FI! [Neotype of Alyssum balkanicum var. calvescens Nyár.]. O. moravensis. Korçë. "District of Moskopolë, W. of Korçë: Çafë Babic, between Moskopolë and Gjergjericë, c. 4800 ft.”, 03/07/1933, A. H. G. Alston \& N. Y. Sandwith, $n^{\circ} 2066$, K! [as Alyssum scutarinum] — "Moskopolë (Voskopoj), $4500 \mathrm{ft}$, bare serpentine slopes, abundant", 20/08/1935, A. H. G. Alston \& N. Y. Sandwith, $n^{\circ} 2563$ [A], K! [as Alyssum scutarinum] - "Mali i Moravë: Drenovë 1100-1500 m serpentinë”, 13/09/1961, E. Kongjika, TIR! [as Alyssum bertolonii subsp. scutarinum ('scardicum')] "Korçë: Voskopojë, njakroj i fihut, në lushkia e Belles", 07/06/1962, N. Faxe, TIR! [as Alyssum bertolonii subsp. scutarinum ('scardicum')] — “distretto di Coriza (Korçë), rilievi a est di Coriza (Korçë), rocce serpentinose lungo la strada tra Boboshticë e Dardhë, 1200 m, 40³2'37.79'N, 2047'3.77'"E”, 16/07/2016, I. Bettarini, L. Cecchi, A. Coppi \& F. Selvi, FI050438, FI! - “distretto di Coriza (Korçë), rilievi a est di Coriza (Korçë), pietraia serpentinosa lungo la strada tra Boboshticë e Dardhë, 1230 m, 40³2'41.14”N, 2047'9.02”'E”, 16/07/2016, I. Bettarini, L. Cecchi, A. Coppi \& F. Selvi, FI050440, FI! - “Distretto di Coriza (Korçë), Moscopolis (Voskopoje), pietraia serpentinosa ca. 3,3 km a sud del paese, 1430 m, 40³6'1.08”N, 20³5'40.27'E”, 09/06/2017, L. Cecchi \& F. Selvi, FI050827, FI050441, FI!"Distretto di Coriza (Korçë), pendici nord-occidentali del monte Moravë sopra il villaggio di Drenovë, lungo la sterrata nella valle del torrente che attraversa il paese, rocce di serpentino, $1020 \mathrm{~m}, 40^{\circ} 34^{\prime} 43.84$ ” N, 2047'46.13" E", 09/06/2017, L. Cecchi \& F. Selvi, FI050828, FI! - "Distretto di Coriza (Korçë), media valle del Devoll, lungo la strada tra Moglicë e Bratilë, 4043'23.82”N, 20²0'28.41'”E, 430 m. Rupi serpentinose. Serpentino.”, 07/10/2017, I. Bettarini \& F. Selvi, FI052166, FI! O. rigida. Elbasan. "Liqeni i Bokanikut rreth $1400 \mathrm{~m}$. serpentinë", 12/06/1960, X. Qosja, TIR! [as Alyssum bertolonii subsp. scutarinum] — "Mali i Bokanikut", 12/06/1960, X. Qosja, TIR! [as Alyssum bertolonii subsp. scutarinum]_ "Librazhd, ana Lindore e lumit te Çermenikës, serpentinë me shtresa honglomeratësh 400 m", 21/04/1962, E. Palihuyi \& Zgjani, TIR! [as Alyssum murale] — "Librazhd-Fshati Qarrishte: gjatë rrugës nga Kodra e Ukut-Kodra e Varrië Xaurrit-Shal e Drenit rreth 1100 m.”, 10/06/1962, M. Demiri \& E. Palihuyi, TIR! [as Alyssum petraeum] — "Librazhd—Fshati Qarrishte, Malet e Kuq, Qafa e Peshuorit dhe Kreshpet 1600 m. serpentinë", 12/06/1962, M. Demiri \& E. Palihuyi, TIR! [as Alyssum murale] - "incolti su substrato ofiolitico (serpentinoso) nei pressi di Librazhd", 11/06/2005, A. Hasko, $n^{\circ} 3306$, FI050869, FI!_-"ELBASAN—Librazhd: Vila Zeneli / dry grassland on compact sandstone, R2, 200 m. a.s.1., WGS84 UTM 34N 458517 4559108”, 01/06/2013, G. Fanelli, Herbarium 
Albanicum n. 18405, RO-HG! [as Alyssum murale]_-"Shebenik-Jablanice National Park-Quendë: faqja e Kronit / Buxus-Juniperus shrubland (lherzolite); 31TDL645931, 1252 m. a.s.l.; R. 4 (179)", 03/06/2013, M. De Sanctis \& G. Fanelli, Herbarium Albanicum n. 17931, RO-HG! [as Alyssum bertolonii subsp. scutarinum] — "distretto di Librazhd, pietraia calcarea presso la vetta del Gur i Pishkashit, $1080 \mathrm{~m}, 41^{\circ} 5^{\prime} 44.53$ ”'N, 20³1'10.12”'E”, 14/07/2016, I. Bettarini, L. Cecchi, A. Coppi \& F. Selvi, FI050435, FI!- "distretto di Librazhd, monte Shebenik, a ca. $1300 \mathrm{~m}$ tra Sutaj e Skënderbej, 41 ${ }^{\circ}$ 9'14.08”N, 20³2’18.60”E”, 15/07/2016, I. Bettarini, L. Cecchi, A. Coppi \& F. Selvi, FI050436, FI050437, FI! - "Distretto di Librazhd, lungo la strada tra Elbasan e Librazhd nella valle dello Shkumbin, circa $11 \mathrm{~km}$ a est-nord-est dal margine orientale del capoluogo, rocce ofiolitiche all'imbocco di una strada sterrata secondaria subito dopo il ponte sul fiume, $220 \mathrm{~m}, 41^{\circ} 10^{\prime} 58.12^{\prime \prime} \mathrm{N}, 20^{\circ} 16^{\prime} 27.74$ 'E”, 08/06/2017, L. Cecchi \& F. Selvi, FI050826, FI!- "Distretto di Librazhd, monte Shebenik, alta valle dello Shkumbin, appena a sud del villaggio di Skënderbej, 920 m, 41 7'54.22”N, 20³3'0.48”'E”, 10/06/2017, L. Cecchi \& F. Selvi, FI050825, FI!- "Distretto di Elbasan, pendici

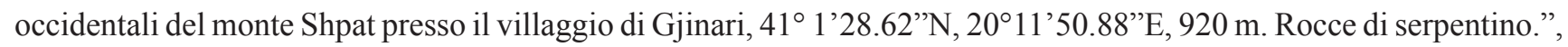
08/10/2017, I. Bettarini \& F. Selvi, FI052161, FI! O. smolikana subsp. glabra. Dibër. "Qafë Shtamë 1000-1200 m. serp. e pjeserisht flysh", sine die, I. Mitrushi \& D. Shuqja, TIR! [as Alyssum bertolonii subsp. scutarinum]_"Qafë Shtamë-Burel”, 21/06/1950, N. Lako, TIR! [as Alyssum bertolonii subsp. scutarinum] —"Qafë Shtamë (German), reth 600 m. serpentinë", 29/05/1959, X. Qosja, TIR! [as Alyssum bertolonii subsp. scutarinum]_-Kunora e Lurës, serpentinë, 2050 m. në zone me gurë”, 10/06/1975, J. Vangjeli, M. Xhulaj \& v. Tartari, TIR! [as Alyssum bertolonii]"distretto di Mat, versante orientale del Maja e Liqenit, alta valle del Mat, appena oltre il passo di Shtamës, $1150 \mathrm{~m}$, 4131’31.94”N, 1954'7.49”'", 18/07/2016, I. Bettarini, L. Cecchi, A. Coppi \& F. Selvi, FI050430, FI050431, FI!"Distretto di Bulqizë, rocce serpentinose lungo la strada che sale da Bulqizë a Krastë, 1030 m, 41²7’34.41"N, 20¹0’31.76"E”, 11/06/2017, L. Cecchi \& F. Selvi, FI050831, FI! - "Distretto di Mat, lungo la sterrata che da Burrel sale al passo di Shtamës, poco sopra Komsi, su serpentino, 720 m, 41³4’30.34”N, 1957'15.10”'E”, 12/06/2017, L. Cecchi \& F. Selvi, FI050839, FI! Durrës. "distretto di Croia (Krujë), versante occidentale del Maja e Liqenit, pietraia serpentinosa sul primo tornante a gomito subito oltre il passo di Shtamës, $1010 \mathrm{~m}, 41^{\circ} 31$ '11.42"N, 1952'51.85"E", 18/07/2016, I. Bettarini, L. Cecchi, A. Coppi \& F. Selvi, FI050432, FI! Elbasan. "Shebenik-Jablanice National ParkHotolish m. Shebenikut / Sesleria caerulescens grassland, ril. 145 (9); 2125 m. a.s.l. UTM WGS 84 34N455303.30 4562045.00; Ultramafic rock", 17/07/2012, M. De Sanctis, Herbarium Albanicum n. 19123, RO-HG! [as Alyssum bertolonii] — “distretto di Librazhd, monte Shebenik, a ca. 1300 m tra Sutaje Skënderbej, 41 '9'14.08"N, 20³2'18.60"E”, 15/07/2016, I. Bettarini, L. Cecchi, A. Coppi \& F. Selvi, FI050433, FI!- "Distretto di Librazhd, monte Shebenik, alta

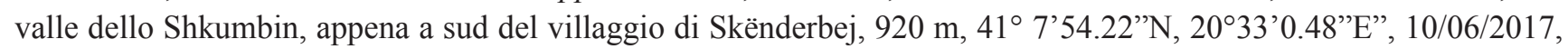
L. Cecchi \& F. Selvi, FI050835, FI050836, FI! Shkodër. "Qyrsaç", 06/06/1958, X. Qosja, TIR! [as Alyssum markgrafii].

Supplementary material: Electronic supplement (Table S1, links to the URIs of type specimens) is available in the Supplementary Data Section of the online version of this article. 